RAFAEL DALBOSCO DOS SANTOS

\title{
O IMPACTO DO DIABETES MELLITUS DO TIPO 1 SOBRE A AÇÃO DA RESPOSTA PROLIFERATIVA ESTIMULADA PELA PROGESTERONA NO AMBIENTE UTERINO DE CAMUNDONGOS
}

Dissertação apresentada ao Programa de Pós-Graduação em Biologia Celular e Tecidual do Instituto de Ciências Biomédicas da Universidade de São Paulo, para obtenção do Título de Mestre em Ciências. 


\section{RAFAEL DALBOSCO DOS SANTOS}

\section{O IMPACTO DO DIABETES MELLITUS DO TIPO 1 SOBRE A AÇÃO DA RESPOSTA PROLIFERATIVA ESTIMULADA PELA PROGESTERONA NO AMBIENTE UTERINO DE CAMUNDONGOS}

Dissertação apresentada ao Programa de Pós-Graduação em Biologia Celular e Tecidual do Instituto de Ciências Biomédicas da Universidade de São Paulo, para obtenção do Título de Mestre em Ciências.

Área de concentração: Biologia Celular e Tecidual

Orientadora: Prof. ${ }^{a}$ Drª Telma Maria Tenório Zorn

Versão original 
DADOS DE CATALOGAÇÃO NA PUBLICAÇÃO (CIP)

Serviço de Biblioteca e Informação Biomédica do

Instituto de Ciências Biomédicas da Universidade de São Paulo

reprodução não autorizada pelo autor

Santos, Rafael Dalbosco dos.

O impacto do Diabetes Mellitus do tipo 1 sobre a ação da resposta proliferativa estimulada pela progesterona no ambiente uterino de camundongo / Rafael Dalbosco dos Santos. -- São Paulo, 2015.

Orientador: Profa. Dra. Telma Maria Tenorio Zorn

Dissertação (Mestrado) - Universidade de São Paulo. Instituto de Ciências Biomédicas. Departamento de Biologia Celular e do Desenvolvimento. Área de concentração: Biologia Celular e Tecidual. Linha de pesquisa: Impacto do Diabetes Mellitus tipo 1 no ambiente uterino de camundongos

Versão do título para o inglês: The impact of type 1 Diabetes Mellitus on the progesterone-mediated cell proliferative response on mice uterine environment.

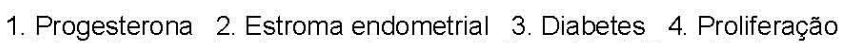
celular 5. Receptor de progesterona 6. Hoxa 10 I. Zorn, Profa. Dra. Telma Maria Tenorio II. Universidade de São Paulo. Instituto de Ciências Biomédicas. Programa de Pós-Graduação em Biologia Celular e Tecidual III. Título. 
UNIVERSIDADE DE SÃO PAULO

INSTITUTO DE CIÊNCIAS BIOMÉDICAS

\begin{abstract}
Candidato(a): $\quad$ Rafael Dalbosco dos Santos.
Título da Dissertação: $\quad$ O impacto do Diabetes Mellitus do tipo 1 sobre a ação da resposta proliferativa estimulada pela progesterona no ambiente uterino de camundongo.
\end{abstract}

Orientador(a): $\quad$ Profa. Dra. Telma Maria Tenorio Zorn.

A Comissão Julgadora dos trabalhos de Defesa da Dissertação de Mestrado, em sessão pública realizada a .... considerou

( ) Aprovado(a) ( ) Reprovado(a)

\begin{tabular}{|c|c|}
\hline Examinador(a): & $\begin{array}{l}\text { Assinatura: ... } \\
\text { Nome: .......... } \\
\text { Instituição: ... }\end{array}$ \\
\hline Examinador(a): & $\begin{array}{l}\text { Assinatura: ... } \\
\text { Nome: .......... } \\
\text { Instituição: ... }\end{array}$ \\
\hline Presidente: & $\begin{array}{l}\text { Assinatura: ... } \\
\text { Nome: .......... } \\
\text { Instituição: ... }\end{array}$ \\
\hline
\end{tabular}


UNIVERSIDADE DE SÃO PAULO

INSTITUTO DE CIÊNCIAS BIOMÉDICAS

Cidade Universitária "Armando de Salles Oliveira"

Av. Prof. Lineu Prestes, 2415 - CEP. 05508-000 São Paulo, SP Brasil

Telefone :(55) (011) 3091.7733 - e-mail: cep@icb.usp.br

\section{Certificado}

Certificamos que o protocolo registrado sob n 125 nas fls. 12 do livro $\mathbf{0 3}$ para uso de animais em experimentação, sob a responsabilidade do Prof(a) $\operatorname{Dr}(a))$ Telma Maria Tenório Zorn, Coordenador (a) da Linha de pesquisa "Influência do diabetes tipo 1 sobre a sinalização da progesterona no ambiente uterino de camundongos" do qual participam o(s) aluno(s) Rodolfo Favaro, Rafael Dalbosco dos Santos, está de acordo com os Princípios Éticos de Experimentação Animal adotado pela Sociedade Brasileira de Ciência de Animais de Laboratório (SBCAL) e foi aprovado pela COMISSÃO DE ÉTICA NO USO DE ANIMAIS (CEUA) em 16.12.2013, com validade de 4 anos.

São Paulo, 18 de dezembro de 2013.

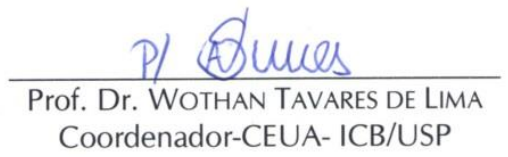

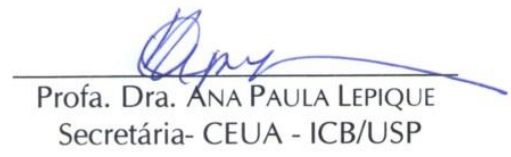




\section{AGRADECIMENTOS}

À minha querida Mãe, Dema Dalbosco dos Santos, que teve como o objetivo de sua vida a educação e formação de seus filhos. Sua dedicação ao trabalho é o meu maior exemplo de como devo encarar os compromissos diários. Obrigado por aguentar a minha ausência e sempre estar me incentivando.

À minha amada esposa, Janaína Colpani, agradeço por ser a minha maior incentivadora, graças a você consegui tirar este sonho do papel e torná-lo realidade. Sou muito feliz de ter você ao meu lado em todos os momentos desta jornada. Agradeço por ser o meu porto seguro para os momentos de alegria e tristeza.

À minha irmã, Francieli Dalbosco dos Santos, obrigado por ser sempre participativa em todos os momentos da minha vida. O seu encorajamento sempre foi o impulso para eu superar todos os obstáculos. Obrigado, por sua preocupação com nossa família e principalmente por suprir minha ausência no cuidado de nossa mãe.

Á Prof. a Telma Zorn, mais do que uma orientadora e sim uma "mãe científica". É um exemplo de educadora, o qual buscarei sempre me inspirar. Agradeço por sua constante preocupação com todos os aspectos da formação de seu orientado. Foi inestimável honra poder conviver e ser um aprendiz da senhora. E principalmente agradeço pela oportunidade e confiança oferecida a minha pessoa, serei eternamente agradecido.

Aos Colegas do LBR \& MEC, a Rodolfo Favaro, grande amigo, colaborador e responsável por me incentivar na minha vinda ao LBR\&MEC. Agradeço por todo o conhecimento cientifico me transmitido, por me ensinar a pensar criticamente. Por sua dedicação e paciência em todas as etapas desde trabalho. Fernanda Correia Barrence, professora na técnica, colega de trabalho, colaboradora e amiga. Obrigado por me ensinar grande parte dos procedimentos utilizados neste trabalho. Agradeço profundamente por esses anos de convivência. À Mychel Raony Morais, amigo e colega, obrigado pela ajuda indispensável na finalização deste trabalho. 
À Vivian Mazucato, do Laboratório Biologia Celular e Molecular de Células Secretoras da Medicina USP - Ribeirão Preto, amiga e colega, não apenas uma irmã adotada de Ribeirão Preto, mais sim uma importante colaboradora no desenvolvimento deste projeto, obrigado pela ajuda e ensinamentos diários.

Á Carol Serrano, do Laboratório de Fisiologia Endócrina: Regulação Hormonal e Expressão Gênica da Fisiologia ICB-USP, pelos seus ensinamentos e ajuda nas técnicas de biologia molecular.

Aos amigos da TQF são poucos os verdadeiros amigos que levamos para toda a nossa vida, obrigado por todos vocês mesmo a distância sempre estarem torcendo por minhas conquistas. A toda ida para minha cidade, vocês foram importante fonte de energia para que eu recarregasse minhas pilhas, para assim, conseguir encarar todos os desafios.

À toda a Família Dalbosco, a todos os meus tios e primos. Sempre presentes nas bases da minha formação. Agradeço pela disposição e constante ajuda.

À Família Colpani, meu sogro Carlos Colpani, sogra Salete Colpani e minha cunhada Maiara Colpani, obrigado por me acolher como membro desta família e pela constante energia positiva.

A todos os funcionários do Departamento de Biologia Celular e do Desenvolvimento, que de alguma forma auxiliaram no desenvolvimento deste trabalho.

Á CAPES, pela bolsa concedida, sem a qual este trabalho não seria possível 
"Depois de escalar uma montanha muito alta, descobrimos que há muitas outras montanhas por escalar."

Nelson Mandela 


\section{RESUMO}

DALBOSCO, R. O impacto do sobre a ação da resposta proliferativa estimulada pela progesterona no ambiente uterino de camundongos. 2015. 86 f. Dissertação (Mestrado em Biologia Celular e Tecidual) - Instituto de Ciências Biomédicas, Universidade de São Paulo, São Paulo, 2015.

O sistema reprodutor de humanos e outras espécies de mamíferos é caracteristicamente cíclico e coordenado por hormônios ovarianos. Durante os ciclos ovarianos e, particularmente, durante a gestação, a proliferação celular mediada pela progesterona (P4) é essencial para a funcionalidade do ambiente uterino. Dessa forma, alterações nesse processo podem de fato, comprometer a reprodução. Dados acumulados mostram que o diabetes do tipo 1 (DM1) está associado a déficits hormonais acompanhados de anormalidades no ciclo reprodutivo e infertilidade. Estudos anteriores do nosso grupo, realizados durante o início da gestação, demonstraram que o diabetes compromete a remodelação da matriz extracelular e a proliferação celular uterina, eventos controlados por hormônios ovarianos. No entanto, o impacto do diabetes sobre a ação da P4 no ambiente uterino ainda não é conhecido. Sabendo-se, que a proliferação celular do ambiente uterino é controlada por estrógeno e P4, a hipótese desse nosso estudo é que o DM1 altere a resposta hormonal da P4 no ambiente uterino de camundongos. Nesse contexto utilizamos o modelo de DM1 induzido por meio de aloxana em camundongos já estabelecido por nosso grupo de pesquisa (Favaro et al., 2013) submetendo fêmeas normoglicêmicas e portadoras de DM1 à ovarectomia e reposição por P4. Observou-se, que as fêmeas DM1 resistem ao procedimento cirúrgico e também ao protocolo de reposição hormonal, garantindo, portanto, a sua utilização como modelo experimental viável. As amostras uterinas foram coletadas e submetidas aos seguintes procedimentos: (I) avaliação da área do estroma uterino e da proliferação das células endometriais por histomorfometria e Imunolocalizaçãode PCNA, respectivamente; (ii) avaliação dos níveis dos receptores de progesterona (PR) por Western blot; (iii) avaliação da distribuição desses receptores por imunohistoquímica; (iv) Análise da expressão gênica da ciclina D1, ciclina E1, p27, Hoxa10 e FGF2 pela PCR em tempo real. Observou-se, que as fêmeas diabéticas, mesmo submetidas á reposição hormonal, apresentaram diminuição da área de estroma endometrial e menor índice de proliferação destas células. Diante desses resultados nossa hipótese foi que a diabetes estaria alterando a dinâmica dos PR. Adicionalmente, as fêmeas diabéticas OVX e tratadas com a P4 apresentaram aumento da isoforma PR-A na fração citoplasmática. A correlação entre os receptores PR-A e PR-B revelou a existência de um aumento da isoforma PR-A no núcleo das fêmeas diabéticas tratadas com P4. Além disso, observou-se a presença de subprodutos do PR, os quais foram modulados tanto pelo DM1 como pela reposição da P4. Registrou-se ainda, que fêmeas diabéticas submetidas ao tratamento hormonal, apresentaram diminuição na expressão do RNAm do fator transcrição Hoxa-10, um estimulador da proliferação das células estromais uterinas. Surpreendentemente, as fêmeas diabéticas não submetidas ao tratamento hormonal exibiram aumento da expressão do RNAm do inibidor ciclo celular p27. Em conjunto, nossos resultados demonstraram que o DM1 interfere negativamente na resposta proliferativa promovida pela $\mathrm{P} 4$ no ambiente uterino, por meio de em um processo que envolve alterações na expressão dos PR e genes que controlam ciclo celular. 
Estes resultados contribuem de modo importante para uma melhor compreensão dos mecanismos biológicos pelos quais o diabetes compromete as funções reprodutivas.

Palavras-chave: Progesterona. Diabetes. Receptor de Progesterona. Estroma Endometrial. Hoxa 10. p27. 


\begin{abstract}
DALBOSCO, R. The impact of type 1 Diabetes Mellitus on the progesteronemediated cell proliferative response on mice uterine environment. 2015. $86 \mathrm{p}$. Masters thesis (Cell and Tissue Biology). - Instituto de Ciências Biomédicas, Universidade de São Paulo, São Paulo, 2015.
\end{abstract}

The reproductive system of humans and other mammalian species is characteristically cyclic and coordinated by ovarian hormones. During ovarian cycle and, particularly during gestation, P4-mediated cell proliferative response is essential to the uterine function. Therefore, alterations is this process actually might compromises reproduction. Accumulated data show that type 1 diabetes (DM1) is associated to hormonal deficits followed by infertility and abnormalities in the reproductive cycle. Previous studies from our research group performed during the beginning of gestation demonstrate that diabetes compromises the extracellular matrix remodeling and uterine cell proliferation, both controlled by ovarian hormones. However, the impact of DM1 on the action of P4 in the uterine environment is still not elucidated. Undoubtedly, estrogen and P4 control the uterine cell proliferation, so the hypothesis of our study is that DM1 alters the hormonal response to P4 in mice uterine microenvironment. In this context, we used a model of alloxan-induced DM1 in mice established by our group (Favaro et al., 2013) subjecting normoglycemic and diabetic females to ovariectomy (OVX) and hormonal replacement therapy with P4. We observed that females with DM1 resist to the surgical procedure and to the hormonal replacement treatment, which make them viable as experimental models. Hence, uterine samples were collected and submitted to the following procedures: $(I)$ evaluation of the uterine stromal area and endometrial cell proliferation response by histomorphometrical analysis and immunohistochemistry to PCNA, respectively; (ii); evaluation of progesterone receptors (PR) levels by Western blot; (iii) evaluation of the distribution of PR by immunohistochemistry and (iv) analysis of genic expression of D1 cyclin, E1 cyclin, p27, Hoxa-10 and FGF2 by real time PCR. Was observed that diabetic females showed a decrease of uterine stromal area and lower proliferation index of uterine fibroblasts, even though these females were subjected to hormone replacement. Thus, our hypothesis was that diabetes might be altering PR dynamic. Additionally, OVX diabetic females treated with P4 present increased levels of PR-A isoform in the cytoplasmic fraction of the uterine cells. The correlation between PR-A and PR-B revealed an increase in the levels of nuclear PR-A in P4treated diabetic females. Moreover, we observed that P4 replacement therapy in DM1 females modulates PR sub products. Diabetic females subjected to hormonal treatment presented decreased levels of mRNA expression of Hoxa-10 transcription factor, a stimulator of proliferation of uterine stromal cells. Surprisingly, diabetic females non-treated with P4 showed an increase mRNA expression of the cell cycle inhibitor p27. Gathered, our results demonstrated that DM1 interferes in a negative way on the P4-mediated proliferative response in the uterine environment by a pathway that involves alterations in the expression of PR and others genes that control the cell cycle. These are new and important results to a better understand of the biological mechanisms by which diabetes affects the reproductive functions. 
Keywords: Progesterone. Progesterone receptor. Diabetes. Endometrial Stroma. Hoxa 10. p27. 


\section{LISTA DE ILUSTRAÇÕES}

Figura 1: Representação esquemática de um ovário e de suas principais

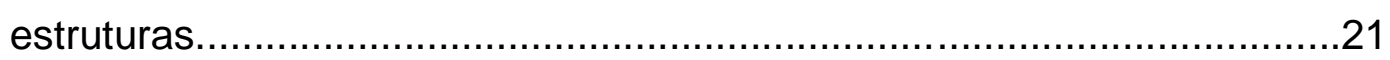

Figura 2: Fotomicrográfica de útero de camundongo não grávido...........................23

Figura 3: Desenho representativo da atuação da progesterona no seu receptor e as principais vias de sinalização.

Figura 4: Desenho esquemático, que demostra a inter-relação dos receptores de progesterona. .30

Figura 5: Esquema destacando as principais fases do ciclo celular e as proteínas que são reguladas pela progesterona no controle da proliferação das células estromais uterinas.

Figura 6: Esquema demostrando as principais etapas experimentais do trabalho e 0 protocolo de reposição hormonal

Figura 7: Citologia de esfregaço vaginal corados por Shorr, amostras coletadas antes da ovarectomia (A, B, C e D) e amostras coletadas após a ovarectomia (E e F) .53

Figura 8: Imunolocalizaçãode PCNA para escolha dos protocolos de reposição hormonal

Figura 9: Cortes transversais de úteros corados por picrosirius-hematoxilina $(A)$; Representação gráfica do peso corpóreo e uterino (B); Representação gráfica da análise histomorfometrica dos compartimentos uterinos (C)

Figura 10: Imunolocalizaçãode PCNA .58

Figura 11: Imuno-blotting para Receptor de Progesterona (A); Quantificação protéica realizada por densitometria óptica (B); Quantificação dos subprodutos dos receptores de progesterona (C).

Figura 12: Imunolocalizaçãodos receptores de progesterona 62

Figura 13: Gráficos da quantificação relativa da expressão gênica por qPCR .64

Figura 14: Gráficos das análises dos níveis séricos dos hormônios esteroides ovarianos. 


\section{LISTA DE TABELAS}

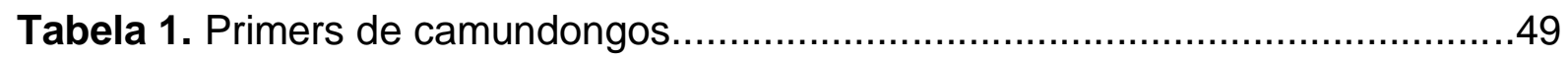

Tabela 2. Parametros fisiopatológicos dos grupos experimentais............................55 


\section{LISTA DE ABREVIATURAS E SIGLAS}

BSA - albumina de soro bovino

Cdk - quinases dependente de ciclina (do inglês: Cyclin Dependent Kinases)

CKI - inibidor de quinases dependente de ciclina (do inglês: Cyclin Dependent

Kinase Inhibitors)

DM - diabetes mellitus

DM1 - diabetes mellitus do tipo 1

E2 - estrógeno

ER - receptor de estrógeno

ERs - receptores de estrógeno

ERa - receptor de estrógeno $\alpha$

ER $\beta$ - receptor de estrógeno $\beta$

FGF - fator de crescimento fibroblasto (do inglês: fibroblast growth fator)

FSH - hormônio folículo estimulante

$\mathrm{g} / \mathrm{mL}$ - gramas por mililitro

h - horas

H2O2 - peróxido de hidrogênio

H2Od - Água destilada

i.p - intraperitoneal

i.v - intravenosa

IGF 1 - Fator de crescimento semelhante à insulina (do inglês: Insulin-like growth factor 1).

$\lg G$ - imunoglobulina tipo $G$

LBR\&MEC - Laboratório Biologia da Reprodução e Matriz Extracelular

LH - hormônio luteinizante

LIF - fator de inibidor leucemia (do inglês: Leukemia inhibitory fator).

MEC - matriz extracelular

mg - miligramas

$\mathbf{m g} / \mathbf{d L}$ - miligramas por decilitro

$\mathbf{m g} / \mathbf{K g}$ - miligrama por quilo

$\mathbf{n g} / \mathbf{m L}$ - nanograma por microlitro

OVX - Ovarectomia

P4 - progesterona 
PBS - tampão fosfato salino

PCNA - antígeno nuclear de proliferação celular (do inglês: Proliferative nuclear cell antigen)

DAB - 3,3-diaminobenzidina

$\mathrm{pg} / \mathrm{mL}$ - picograma por microlitro

PR - receptor de progesterona

PR-A - receptor de progesterona A

PR-B - receptor de progesterona B

PRs - receptores de progesterona

qPCR - PCR quantitativa em tempo real

S.C - subcutâneo

SDS - dodecil sulfato de sódio

T.A - temperatura ambiente

$\boldsymbol{\mu m}$ - micrometros

$\boldsymbol{\mu g}$ - microgramas 


\section{SUMÁRIO}

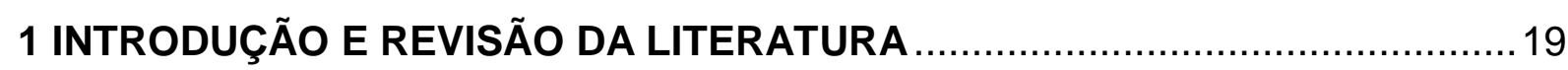

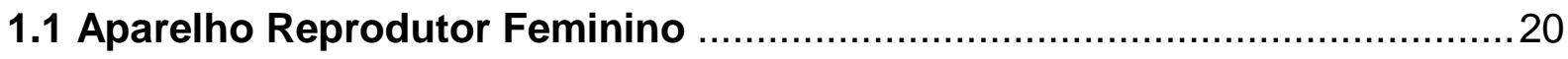

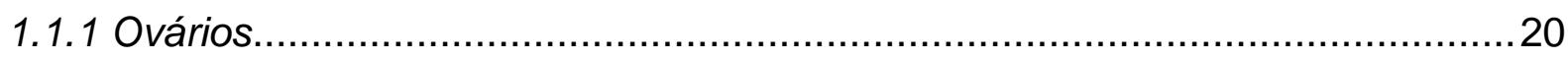

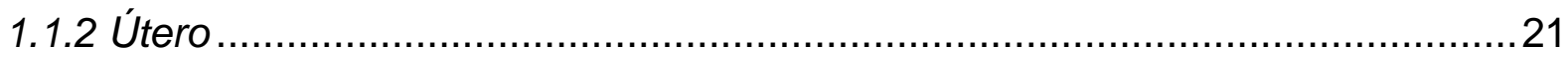

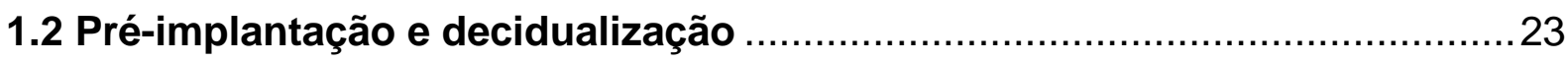

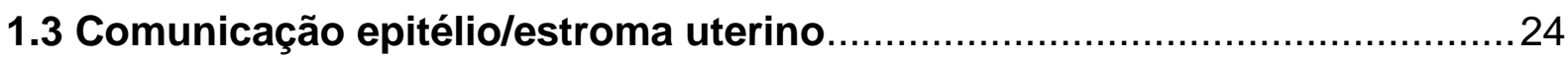

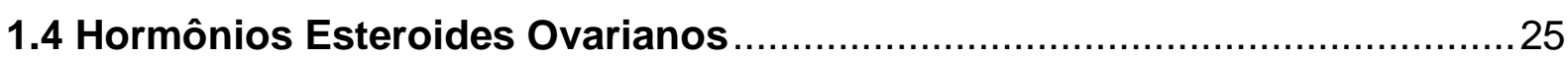

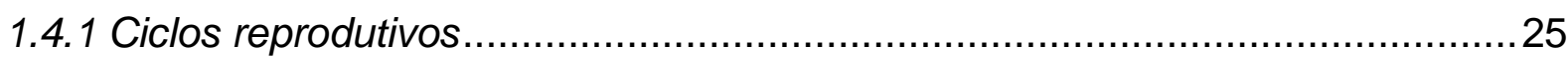

1.4.2 Síntese dos hormônios esteroides e controle hipotálamo-hipófise .................25

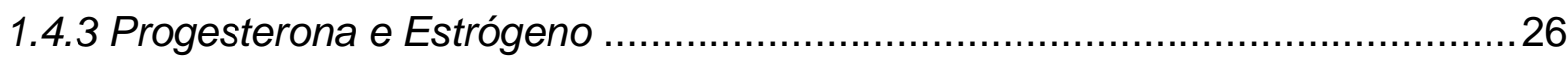

1.4.4 Receptores dos hormônios esteroides ovarianos ................................... 26

1.4.5 Os Receptores de Progesterona (PR-A e PR-B) ................................... 28

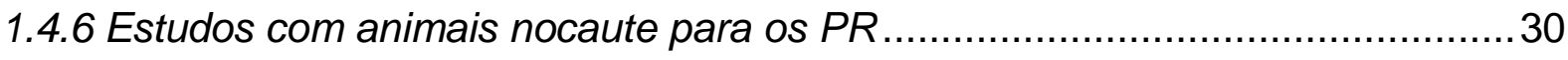

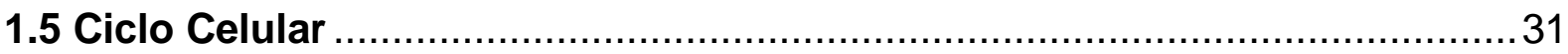

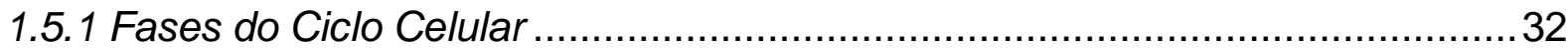

1.5.2 Mecanismos de controle do ciclo celular ............................................ 33

1.5.3 Controle hormonal da proliferação celular .............................................. 34

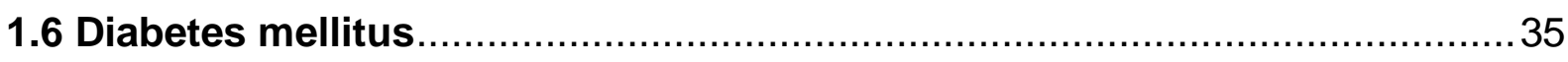

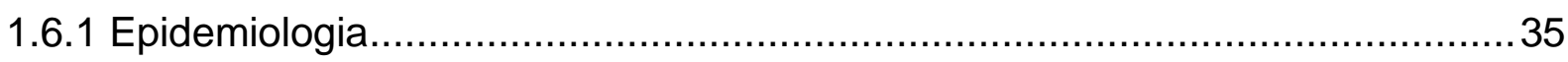

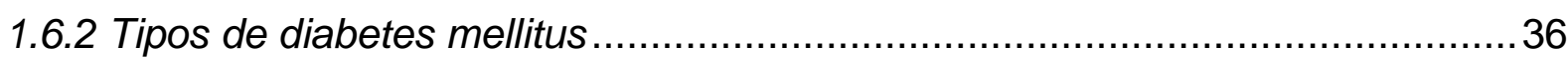

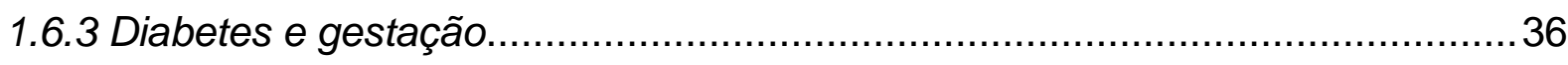

1.6.4 Contribuições do LBR \& MEC em modelo de diabetes tipo 1 e gestação.........38

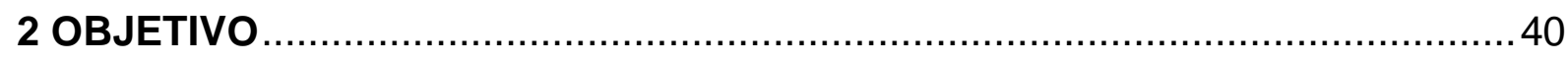

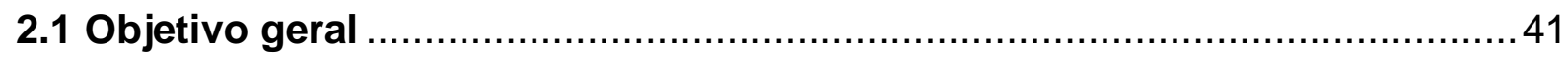

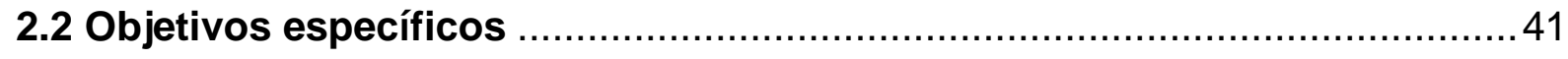

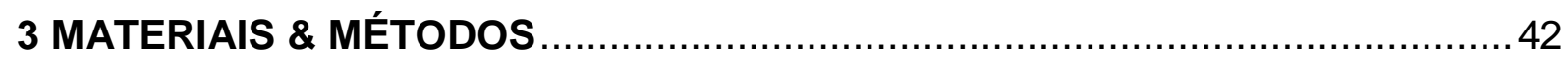


3.1 Animais e sua manutenção .43

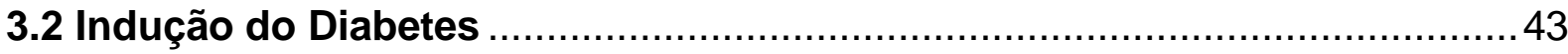

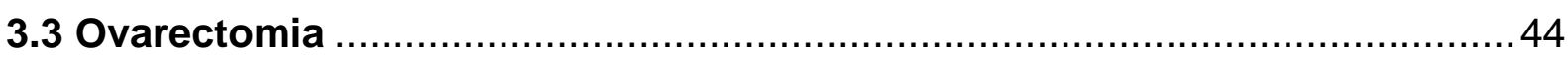

3.4 Esfregaço Vaginal e Coloração de Shorr ………....................................... 44

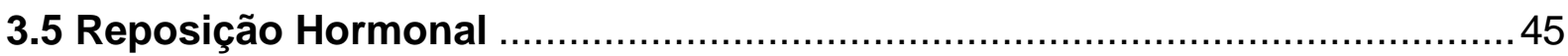

3.6 Coleta e processamento das amostras ……........................................... 46

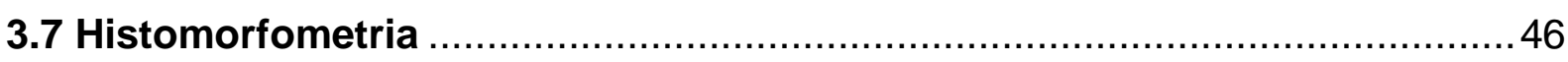

3.8 Imunolocalizaçãode PCNA e Receptor de Progesterona (PR) …................47

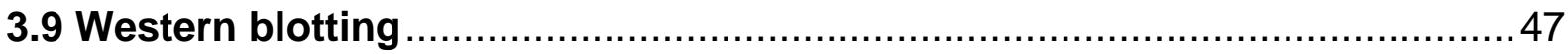

3.10 Análise da expressão do RNAm pela PCR quantitativa em tempo real .....48

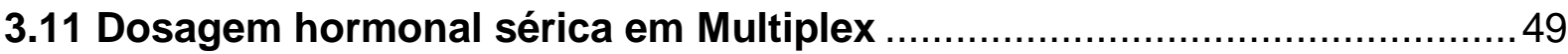

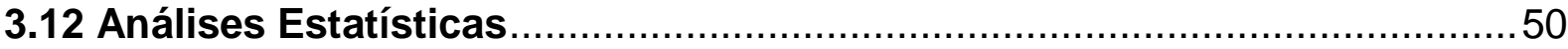

4 RESULTADOS

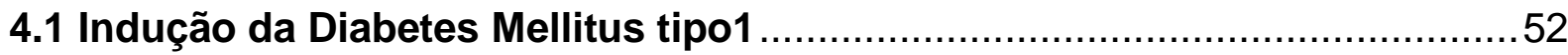

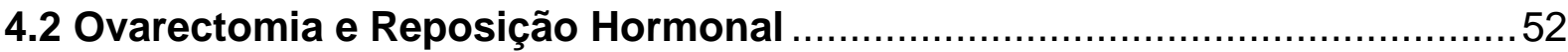

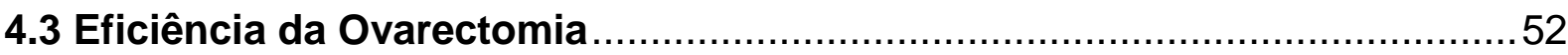

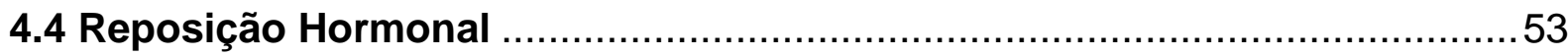

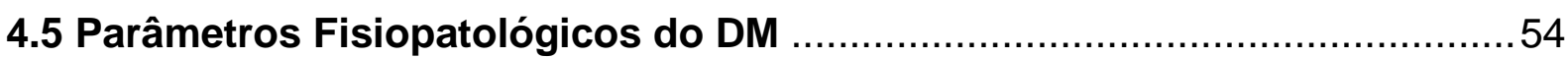

4.6 Peso Uterino e Histomorfometria do Endométrio........................................55

4.7 Índice de Proliferação das Células Estromais ...........................................55

4.8 Níveis Proteicos dos Receptores de Progesterona …………………........59

4.9 Distribuição dos Receptores de Progesterona nos Tecidos Uterinos .........59

4.10 Análises da Expressão Gênica PR-B, PRA+B, das Ciclinas D1, E1 p27,

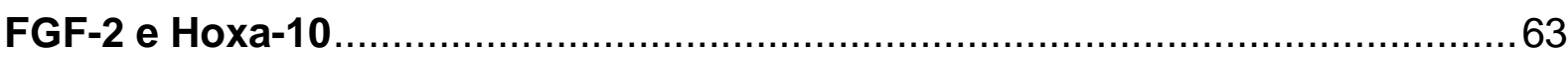

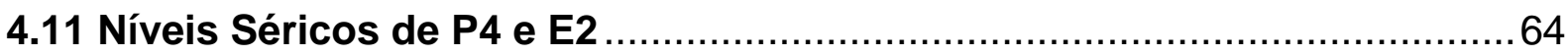

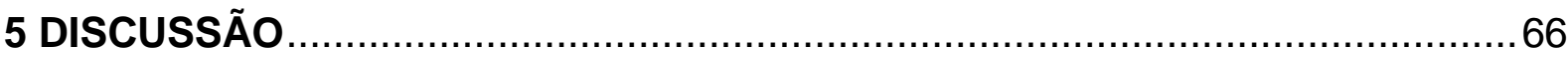

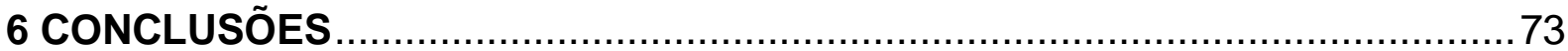

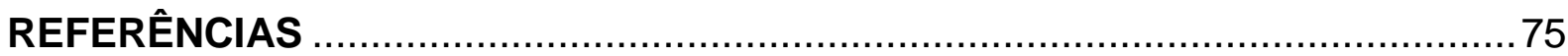


APÊNDICE - Protocolo da técnica histoquímica do Picrosirius ...............................866 
1 INTRODUÇÃO E REVISÃO DA LITERATURA 


\subsection{Aparelho Reprodutor Feminino}

O aparelho reprodutor feminino é responsável pela produção dos gametas femininos e por criar um ambiente hormonalmente e morfologicamente adequado para a sua fertilização. Adicionalmente, tem a função vital de manter o embrião até o seu completo desenvolvimento. O conjunto de órgãos que compõe este sistema é formado por dois ovários, duas tubas uterinas, o útero e a vagina. Da puberdade até a menopausa, estes órgãos são submetidos a mudanças morfofuncionais cíclicas orquestradas por uma precisa alternância nos níveis dos hormônios esteroides ovarianos (JUNQUEIRA; CANEIRO, 2008).

\subsubsection{Ovários}

Os ovários são glândulas mistas que possuem duas funções principais: i) secreção dos hormônios esteroides sexuais ii) formação, desenvolvimento e liberação dos ovócitos a partir de gonócitos precursores. Em roedores o par de ovários está localizado na parede dorsal do corpo, lateralmente aos rins. A superfície do ovário é recoberta por um epitélio pavimentoso ou cúbico simples, denominado de epitélio germinativo, o qual é apoiado por um tecido conjuntivo denso, denominado de túnica albugínea. Subjacentemente à túnica albugínea, observamse duas regiões distintas nos ovários: a medula e a córtex (Figura 1). A medula é a porção central do órgão constituída principalmente por tecido conjuntivo frouxo ricamente vascularizado. É através da medula que ocorre a entrada e saída dos sistemas vascular, linfático e nervoso. A córtex é a porção periférica do ovário e circunda a medula. Ela exerce ações biológicas sobre todo o organismo, pois, é na córtex, que ocorre o desenvolvimento dos folículos ovarianos e consequente produção dos hormônios ovarianos progesterona (P4) e estrógeno (JUNQUEIRA; CANEIRO, 2008; RUGH, 1968) 


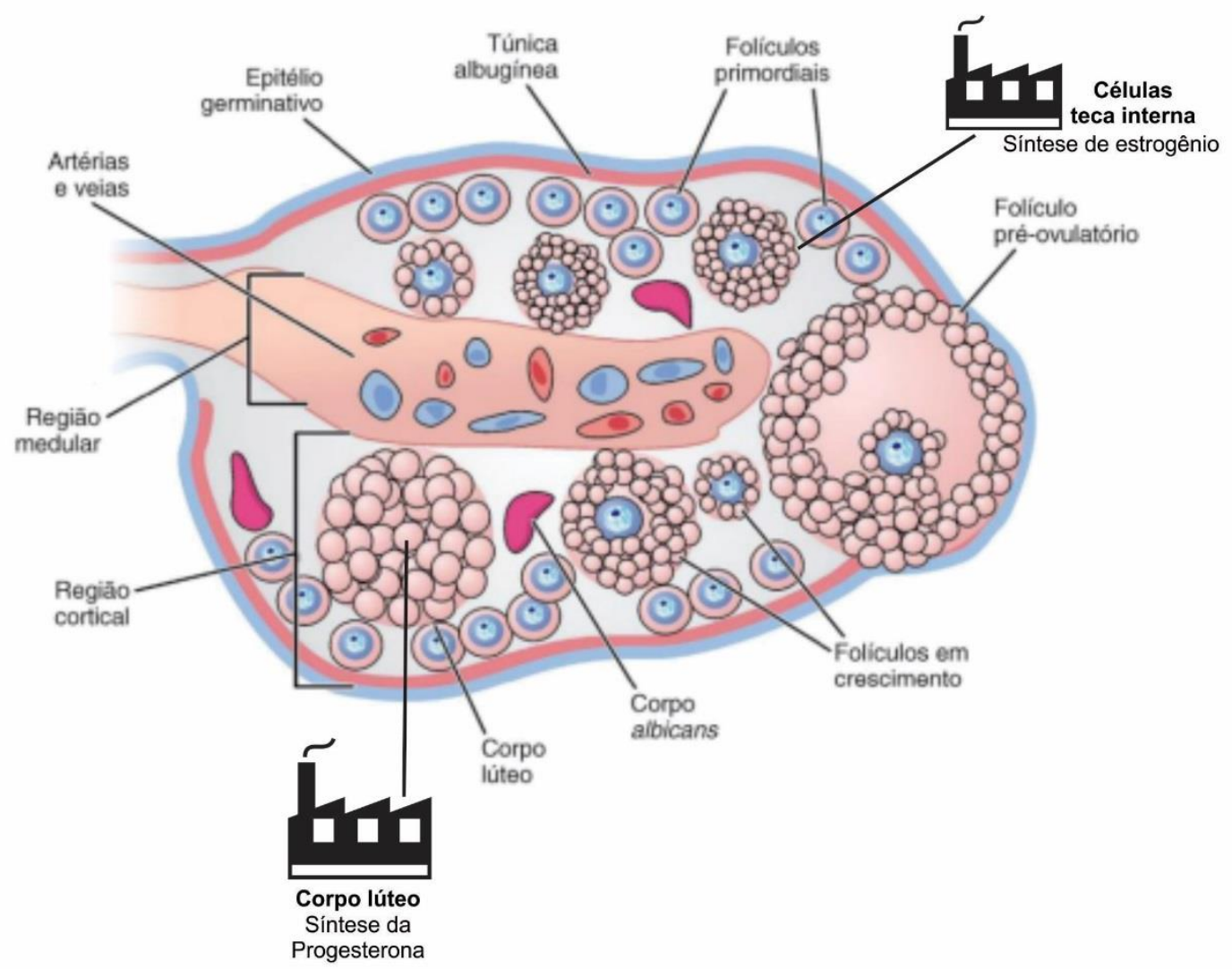

Figura 1. Desenho esquemático representando um ovário com os seus principais componentes e regiões de produção de hormônios esteroides ovarianos (Adaptado: JUNQUEIRA; CARNEIRO, 2008).

\subsection{2 Útero}

O útero é um órgão com características especiais, frequentemente denominado de "imunologicamente privilegiado". Isso se deve à sua capacidade de abrigar um organismo que the é geneticamente diferente, e proporcionar a esse, um ambiente adequado para o desenvolvimento (ABRAHAMSOHN; ZORN, 1993). De fato, é lícito afirmar que, "não existe outro órgão em um organismo adulto, que no exercício de suas funções normais exiba, ciclicamente, um conjunto tão amplo de adaptações morfológicas e funcionais" (GLASSER et al., 2002).

De acordo com a espécie do animal, o útero pode apresentar formas anatômicas diversas. Em humanos, o útero tem um formato de pêra enquanto que em roedores o útero é formado por dois cornos que se unem na região da cervix 
vaginal. Cada um dos cornos uterinos é sustentado por um ligamento (mesométrio) que se estende ao longo de todo o corno uterino. O mesométrio é constituído de tecido conjuntivo muito vascularizado, bem como por fibras continuas de musculo liso. Estruturalmente, o útero é composto por um compartimento mucoso interno denominado de endométrio o qual é revestido por túnicas de músculos lisos que constituem o miométrio. $O$ endométrio é composto por tecido conjuntivo frouxo (estroma uterino). Os fibroblastos uterinos apresentam características especiais, pois são capazes de responder aos hormônios esteroides ovarianos. Adicionalmente, durante a gestação ou pseudogestação, os fibroblastos endometriais são capazes de sofrer um processo de transdiferenciação em um tipo especial de célula denominado célula decidual. No endométrio existem glândulas tubulares uterinas originadas de evaginações do epitélio da luz para o estroma, as quais exercem importantes funções biológicas na fase secretora, como também durante a implantação embrionária. Em camundongos o miométrio é composto por duas camadas de fibras musculares lisa. A camada muscular circular externa e a camada muscular longitudinal interna, essas camadas são conectadas por tecido conjuntivo. 


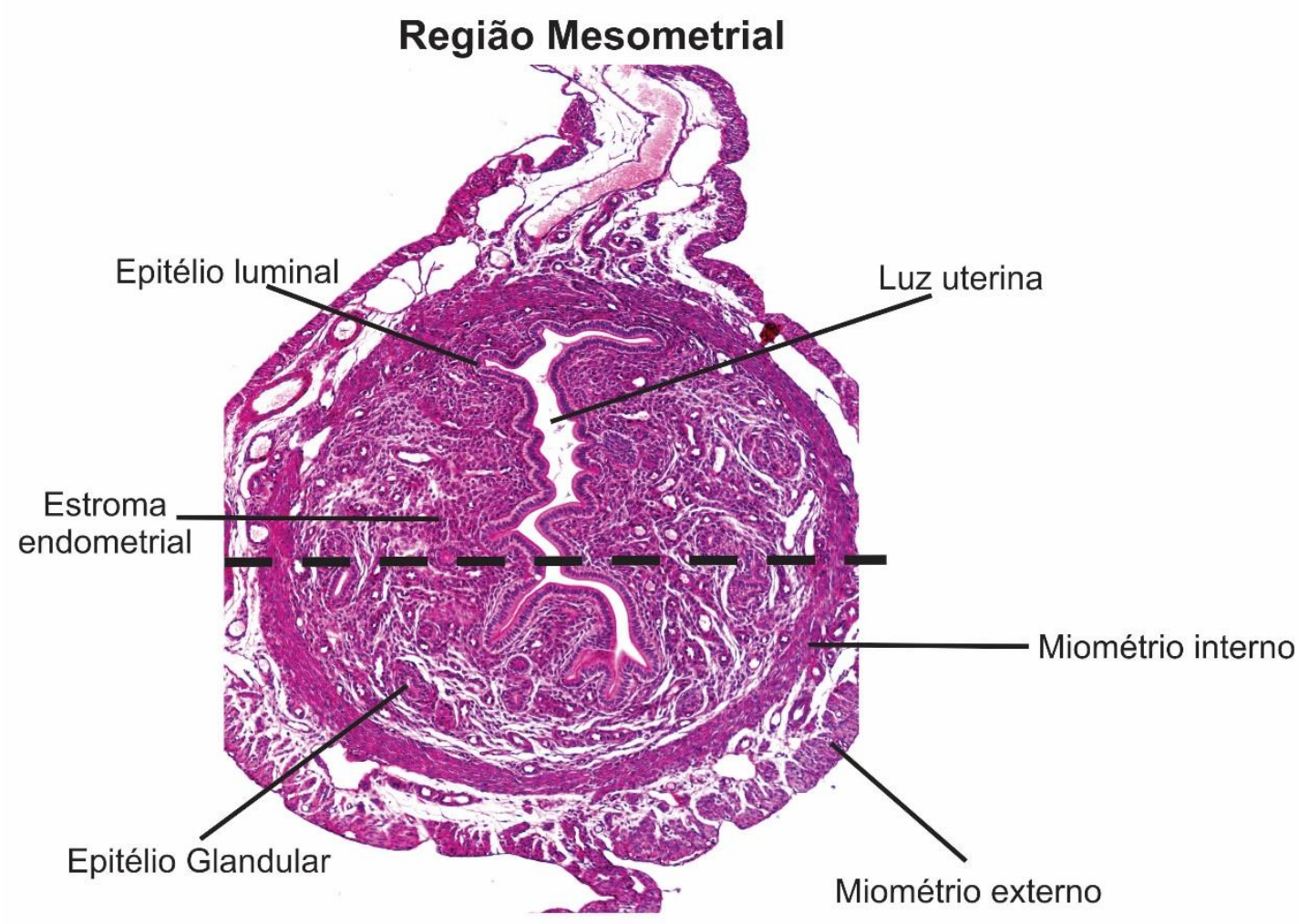

Região Antimesometrial

Figura 2. Corte transversal de útero de camundongo não grávido.

\subsection{Pré-implantação e decidualização}

Em preparação para a gestação e, sobretudo, durante o período gestacional ocorre uma série de modificações estruturais, celulares e moleculares no ambiente uterino para receber o embrião e fornecer a este as condições necessárias para o seu desenvolvimento. Como já informado, o útero é composto por compartimentos constituídos por diferentes tipos de tecidos que abrigam tipos celulares específicos. Cada um destes compartimentos sofre proliferação, diferenciação e apostose em fases específicas, ao longo do ciclo reprodutivo e, particularmente ao longo da gestação. Em camundongos a gestação tem a duração de aproximadamente 21 dias. A implantação ocorre no final do $4^{\circ}$ ou no início do $5^{\circ}$ dia de gestação (REINIUS, 1967). No período pré-implantacional as alterações dos níveis de E2 e P4 promovem intensa remodelação do endométrio. No $3^{\circ}$ dia de gestação ocorre 0 aumento dos níveis de P4 desencadeando a proliferação dos fibroblastos uterinos, 
um processo crucial para determinação do estado receptivo do útero (ZORN et al., 2003). A partir do estimulo da implantação, dado pelo contato do embrião com o epitélio uterino, as células estromais se diferenciam em uma "nova" estrutura transitória denominada de decídua. A decídua decorre da transdiferenciação de fibroblastos endometriais em um novo tipo de célula denominada célula decidual. Estas células deixam de ter a morfologia de fibroblastos e passam a ser volumosas, poliédricas, justapostas e conectadas por junções aderentes e comunicantes típicas de células epiteliais. $O$ fenômeno de decidualização do endométrio promove o meio ambiente adequado para a implantação do embrião, controlando a invasão do trofoblasto além de favorecer a placentação (ABRAHAMSOHN; ZORN, 1993). Estes processos ocorrem quando o perfil hormonal é dominado pela $\mathrm{P} 4$, um hormônio essencial para a implantação e desenvolvimento embrionário. Alterações nos processos proliferativos e de diferenciação destas células impedem o estabelecimento e desenvolvimento normal da gestação.

\subsection{Comunicação epitélio/estroma uterino}

Existem interações reciprocas entre as células estromais e epiteliais uterinas. Ambos os compartimentos interagem por vias de sinalização parácrina que regulam diferentes processos biológicos-chave como proliferação e diferenciação dos tecidos uterinos. Contribuições do Laboratório de Biologia da Reprodução \& Matriz Extracelular (LBR\&MEC) e de outros grupos de pesquisa tem demonstrado 0 envolvimento de moléculas da matriz extracelular (MEC), fatores de crescimento, citosinas, fatores de transcrições e receptores hormonais, neste importante diálogo (HANTAK et al., 2014). Fatores epiteliais como o LIF (Do inglês: Leukemia inhibitory factor) também participa na coordenação das funções exercidas pelo estroma uterino. O LIF é produzido principalmente pelo epitélio glandular e ativa a proliferação e decidualização das células estromais (CHENG et al., 2001). Outro exemplo de comunicação epitélio-estroma uterino é dado pela proteína Indianhedgehog. Expressa nos epitélios luminal e glandular, a Indianhedgehog controla os processos de proliferação e diferenciação das células estromais (MATSUMOTO et al., 2002; PARIA et al., 2001). Adicionalmente, fatores produzidos por células estromais, também exercem ações nas células epiteliais. Um desses 
fatores é o IGF-1 (Do inglês: Insulin-like growth factor 1) um peptídeo de hormônio que promove crescimento celular. O IGF-1 é expresso apenas por células estromais durante implantação, mas, possui abundante número de receptores nas células do epitélio luminal e glandular (BAKER et al., 1996; KAPUR et al., 1992). Destacam-se ainda os receptores dos hormônios esteroides ovarianos que exercem forte função parácrina (epitélio/estroma - estroma/epitélio) reprimindo e/ou estimulando as principais respostas uterinas (LI et al., 2011; PAWAR et al., 2015).

\subsection{Hormônios Esteroides Ovarianos}

\subsubsection{Ciclos reprodutivos}

Em humanos, o estabelecimento da maturidade sexual é determinado pelo início do ciclo menstrual o equivalente ao ciclo estral nos roedores. Os ciclos reprodutivos decorrem de variações nos níveis dos hormônios esteroides sexuais em um tempo determinado. Em humanos a duração do ciclo menstrual é em torno de 28 dias; já o ciclo estral dos roedores tem a duração média de 4 a 5 dias. As fases do ciclo estral podem ser determinadas por meio da técnica de esfregaço vaginal e coloração de Shorr (SHORR, 1941). O epitélio vaginal é altamente responsivo aos hormônios esteroides ovarianos e, dependendo dos níveis de hormônios circulantes, apresentam diferenças marcantes na quantidade e nos estágios de diferenciação de suas células (ALLEN, 1927). São quatro as fases observadas no ciclo estral: proestro, estro, metaestro e diestro. Dessas, as mais marcantes são o estro e o diestro. A fase de estro é aquela em que a fêmea está receptiva ao macho e na qual o E2 é o hormônio dominante; o diestro é a fase mais longa do ciclo e apresenta os níveis mais altos de P4. O proestro e o metaestro são fases intermediárias rápidas e transitórias.

\subsubsection{Síntese dos hormônios esteroides e controle hipotálamo-hipófise}

O controle da biossíntese dos hormônios esteroides ovarianos E2 e P4 decorre de uma ação sincronizada de dois hormônios secretados pelo eixo hipotálamo-

hipófise: hormônio folículo estimulante (FSH) e hormônio luteinizante (LH). Um 
aumento nos níveis de FSH ativa o folículo quiescente levando à proliferação e crescimento as células da camada granulosas e dos fibroblastos que envolvem o ovócito. Estas modificações criam regiões de células especializadas como as células da teca interna, que sintetizam o E2. Em contra ponto, o aumento dos níveis de LH, que ocorre mais tardiamente, está relacionado ao crescimento e maturação do folículo e, consequentemente, com a indução da ovulação. Após a liberação do ovócito o LH estimula as células foliculares maduras a se diferenciarem em uma glândula endócrina temporária denominada de corpo lúteo. Os corpos lúteos remanescentes são os principais responsáveis pela síntese da P4. (Figura 1). Na ausência de acasalamento os corpos lúteos sofrem regressão morfofuncional, reduzindo a produção de P4. Caso ocorra a fertilização os corpos lúteos são mantidos, e estimulados a se desenvolverem, aumentando assim a secreção da P4. A secreção de altos níveis de P4 pelo corpo lúteo é um dos principais responsáveis pela manutenção do estado de gravidez nos primeiros dias gestacionais, até ocorra à completa formação da placenta (CARSON et al., 2000; LURIE et al., 1966; TUCKEY, 2005).

\subsubsection{Progesterona e Estrógeno}

Os hormônios esteroides sexuais controlam os processos fundamentais da morfofisiologia reprodutiva dos mamíferos. Ambos E2 e P4 coordenam a gametogênese, o comportamento sexual além da gestação e lactação (COURSE et al., 2006). Os hormônios E2 e P4 são moléculas regulatórias de natureza lipídica, sintetizados a partir do colesterol. Estes hormônios são lipossolúveis e, portanto, são capazes de se deslocar através da membrana plasmática das células alvos. No entanto, a ação hormonal é dependente da ligação desses hormônios nos seus receptores específicos.

\subsubsection{Receptores dos hormônios esteroides ovarianos}

Os receptores de hormônios esteroides são membros de uma superfamília de receptores nucleares. Estruturalmente, as proteínas dos receptores nucleares se organizam em diferentes domínios funcionais todas elas com influência na atividade 
funcional do receptor. i) A porção N-terminal (Domínio A/B ou DNT) exerce atividade transcricional e de correlação com vias de sinalização intercelulares; ii) A região de ligação ao DNA (Domínio $C$ ) confere a especificidade do receptor a seus genes alvos; iii) A região $\mathrm{C}$-terminal (Domínio $\mathrm{E}$ e $\mathrm{LBD}$ ) é o local que determina a especificidade do receptor ao hormônio ligante. (COURSE et al., 2006). Em suma, os receptores de hormônios esteroides são também reconhecidos como fatores de transcrição; a ligação do hormônio ao seu receptor promove uma modificação conformacional do receptor. Esta mudança conformacional faz com que o receptor ative as regiões transcricionais, ou interaja com as vias de sinalização. As proteínas de receptores hormonais estão distribuídas tanto no citoplasma como no núcleo das células que sofrem controle hormonal de E2 e P4. As principais vias de ação destes receptores esteroides são: a via genômica e via não-genômica. Na via genômica os receptores nucleares atuam mediando uma ação genômica direta; o receptor contém elementos responsivos em suas regiões promotoras, que ativam a expressão de genes (via de sinalização clássica ou nuclear). Na via não-genômica o receptor interage acionando cascatas de sinalização intracelulares, que indiretamente irão ativar a transcrição de genes alvos (BOONYARATANAKORNKIT; EDWARDS, 2007; GELLERSEN et al., 2009; LEONHARDT et al., 2003) representado na figura 3 e 4. Estes receptores regulam a expressão de diversos genes, como aqueles que codificam fatores de transcrição, de moléculas que regulam o ciclo celular, de fatores de crescimento e de componentes da MEC.

Foram descritas duas principais isoformas do receptor de estrógeno (ER), denominadas ERa e ERß, codificadas por genes distintos. É importante destacar que a ativação dos ERs regula a expressão dos receptores de progesterona (PR) no ambiente uterino (KURITA et al., 2000), demonstrando a atuação conjunta de E2 e P4. 


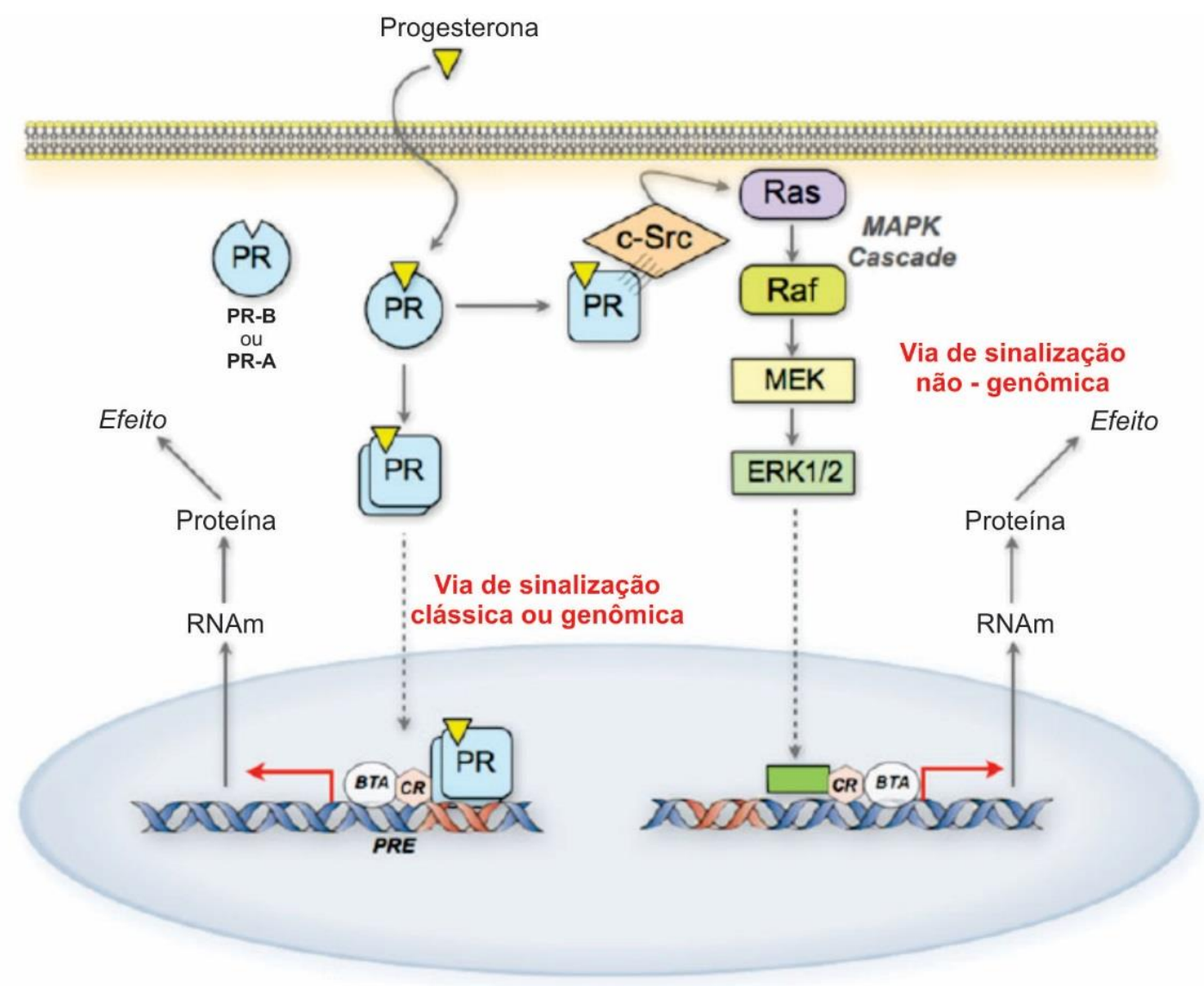

Figura 3. Desenho representativo da atuação da progesterona no seu receptor e as principais vias de sinalização (PATEL et al., 2015).

\subsubsection{Os Receptores de Progesterona (PR-A e PR-B)}

A existência de dois promotores distintos localizados no gene do PR permite a formação de duas isoformas funcionais dessa proteína o PR-A e PR-B. As isoformas são expressas de modo diverso dependendo do tipo celular e das condições fisiopatológica (CONNEELY et al., 1989; KASTNER et al., 1990). Poucos estudos demonstram a distribuição destes receptores no ambiente uterino, sendo que os principais trabalhos disponíveis na literatura são estudos in vitro com linhagens celulares humanas (AUPPERLEE; HASLAM, 2007; MOTE et al., 2015). Apesar da homologia génica de algumas proteínas de humanos quando comparadas as de camundongos, existe um único estudo demostrando a distribuição in vivo destes receptores em camundongos (MOTE et al., 2006). O principal obstáculo para a identificação é a limitação técnica na produção de anticorpos contra o PR-A, devido 
à homologia proteica com o PR-B. Mote e colaboradores (2006) desenvolveram anticorpos, que de acordo com grupo, são capazes de detectar ambas isoformas. Utilizando técnicas imuno-histoquímicas esses autores observaram a distribuição dos receptores no útero nas fases do ciclo estral. Observaram, que os PR-A e PR-B são amplamente distribuídos nas células do estroma endometrial e miométrio. No epitélio glandular, o PR-A é detectado apenas no proestro, enquanto o PR-B é detectado em todas as fases do ciclo. Entretanto, apenas o PR-B foi imunodectado no epitélio luminal (MOTE et al., 2006). Estes dados são conflitantes com os demais da literatura, que descrevem que as isoformas do PR-A e PR-B possuem pouca equivalência funcional, levando suas sinalizações a terem efeitos distintos. O PR-A atua em parte como repressor da expressão de genes ativados pelo PR-B (VEGETO et al., 1993). Esta diferença de atuação decorre do fato de que o PR-B contem um trecho adicional na porção $\mathrm{N}$-terminal com cerca de 165 aminoácidos, responsável pela ativação da transcrição de genes específicos, que confere ao PR-B, uma maior atividade transcricional (Figura 4). Ressalta-se, que o funcionamento normal do útero, requer uma ampla distribuição de ambos os receptores. 

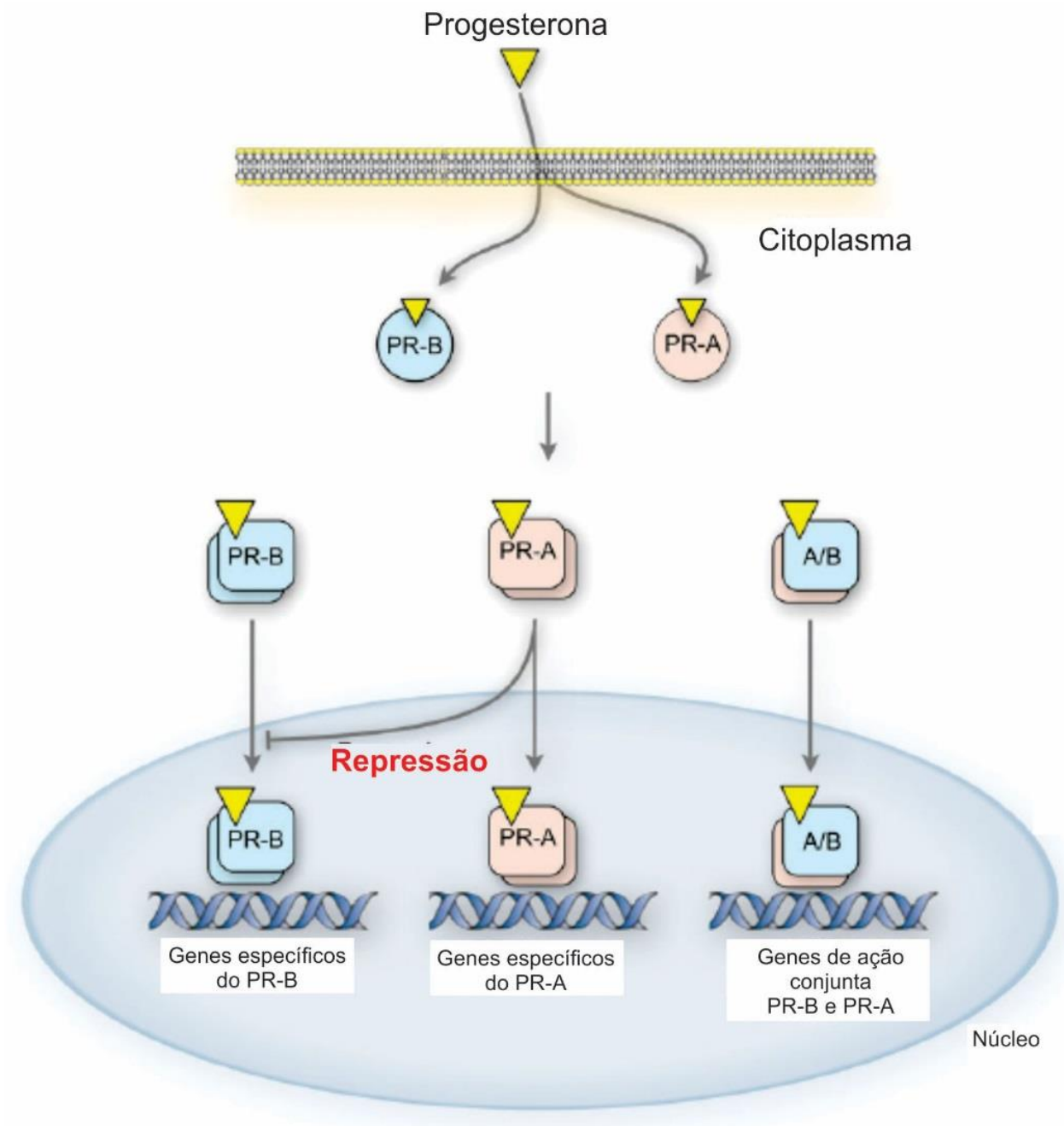

Figura 4. Desenho esquemático, que demostra a inter-relação dos receptores de progesterona (PATEL et al., 2015).

\subsubsection{Estudos com animais nocaute para os $P R$}

Com o intuito de esclarecer as distinções entre as ações da P4 e do E2 e entender melhor as funções fisiológicas dos seus receptores foram iniciados estudos com bloqueadores farmacológicos para ambos os respectivos receptores. $\mathrm{O}$ uso de antagonistas para o PR, como o mifepristone (RU486), rendeu resultados valiosos. A administração deste fármaco provoca a inibição da ovulação e retardamento da maturação uterina (LAKHA et al., 2007; SPITZ et al., 1994). Similarmente, a injeção do inibidor PRs durante a gestação induz aborto, perda fetal e parto, dependo da idade gestacional (CHWALISZ, 1994; SHAW et al., 2013). Estes dados tornaram evidente, que a ação da $\mathrm{P} 4$ nos seus receptores é essencial para o funcionamento normal do útero. 
Com o surgimento de estudos focados na geração de animais geneticamente modificados criaram-se modelos experimentais de nocautes visando a entender melhor os papéis específicos de cada isoforma do PR em mediar as ações da P4. Nesses estudos, todos os camundongos nocautes se desenvolvem normalmente até o estágio adulto sem fenótipos exógenos. O nocaute para ambas isoformas do PR provoca efeitos similares aos observados quando da utilização do mifepristone (RU486) tais como: promoção de imparidades no comportamento sexual, problemas neuroendócrinos, falha na ovulação, disfunções uterinas, alterações na diferenciação de glândulas mamárias e na morfogênese de seus ductos (CHAPPELL et al., 1997; LYDON et al., 1995; MANI et al., 1996).

Quando a ação das isoformas são avaliadas isoladamente observa-se, que os nocautes para PR-A são inférteis. Além do mais, os úteros dos camundongos nocautes PR-A são incapazes de decidualizar por indução artificial. Conclui-se, portanto, que a isoforma do PR-A é essencial para o desenvolvimento normal das funções uterinas durante a implantação. Em contra partida, os animais com nocaute de PR-B possuem alterações fenotípicas mais amenas tal como descontroles na atividade de proliferação dos compartimentos uterinos. Em suma, esses conjuntos de dados demonstram que o PR-A é necessário para a função normal do epitélio e estroma endometriais, e que o PR-B controla a hiperplasia epitelial, que é reprimida pelo PR-A. Ambos receptores medeiam ações anti-inflamatórias do endométrio (FRANCO et al., 2008; MULAC-JERICEVIC et al., 2003; MULAC-JERICEVIC et al., 2000). A relação dos níveis de PR-A/PR-B são cruciais para a resposta uterina normal, o aumento da expressão de alguma das isoformas promove um crescimento uterino descontrolado e hiperplasia do endométrio. Assim, podem estar relacionadas a lesões atípicas, endometrioses e doenças inflamatórias pélvicas (FLEISCH et al., 2009).

\subsection{Ciclo Celular}

Com algumas exceções, como é o caso dos neurônios, a grande maioria das células de um organismo adulto exercem constante renovação para garantir a manutenção das funções teciduais. O fino controle dos eventos, que levam à proliferação e diferenciação celular são essenciais para manutenção da vida e também para evitar o aparecimento de doenças proliferativas. As células são 
geradas de outras células, e a única via para gerar mais células é a divisão celular daquelas já existentes (ALBERTS et al., 2007). O processo de geração de novas células obedece a um padrão cíclico. Inicia-se pelo aumento coordenado da quantidade de moléculas que a célula possui, seguido de duplicação do material gênico com posterior divisão do seu núcleo e citoplasma. No seu conjunto este processo é denominado de ciclo celular. A compreensão dos mecanismos de controle do ciclo celular é essencial para o entendimento de diversos processos biológicos entre os quais estão o desenvolvimento embrionário, envelhecimento, reparação tecidual e geração de doenças (JUNQUEIRA; CARNEIRO, 2005; FAVARO, 2013).

\subsubsection{Fases do Ciclo Celular}

Estudos utilizando a técnica de radioautografia identificaram, que a síntese e a duplicação do DNA, ocorrem em etapas ou fases delimitadas por intervalos denominadas de Gap. O conjunto destes dados determinaram que o ciclo celular é composto por quatro etapas sequenciais: G1 (gap1) - S (síntese DNA) - G2 (gap2) que em conjunto constituem a interfase, e a fase $M$ (mitose) (figura 5). A fase G1 é um momento célula específico, que determina a duração total do ciclo, isso é, o tempo que uma célula leva para sofrer uma nova divisão celular. Por essa razão G1 é a fase com maior tempo de duração. Nesta etapa a célula tem duas opções: i) preparar-se para uma nova divisão celular; ii) permanecer em estado de G1 prolongado (quiescência) denominado de G0. Neste momento, portanto, a célula passa pelo principal ponto de restrição; a superação deste ponto e, consequente progressão para a etapa seguinte, Fase $\mathbf{S}$, resulta no comprometimento da célula com o ciclo celular completo. A Fase $\mathbf{S}$ ocupa um terço de todo o ciclo celular; Seu tempo de duração é mais constante, em média \pm 8 horas, nos diferentes tipos celulares. Nessa fase, a célula ativa seus complexos replicativos, que leva a duplicação de seu material genético. A fase G2 é uma fase rápida com duração \pm 4 horas durante as quais a célula verifica se houve erros na duplicação do DNA, além de dar inicio à condensação da cromatina. A última etapa do ciclo ocorre na fase Fase $\mathbf{M}$, que é a etapa do ciclo de menor duração \pm 2 horas. Nessa fase ocorre a separação dos cromossomos em duas cromátides irmãs e posterior citocinese: processo pelo qual a célula divide o seu citoplasma gerando duas células filhas com 
mesmo número de cromossomos da célula de origem (BASERGA; WIEBEL, 1969; PARDEE, 1974). Em resumo, a interfase composta por $\mathrm{G} 1$, S e G2, é o período em que a célula se prepara e verifica sua capacidade proliferativa. A mitose é momento de divisão equitativa do material gênico entre as duas novas células filhas.

\subsubsection{Mecanismos de controle do ciclo celular}

Considerando o papel-chave desse processo, existem diversos mecanismos de controle e pontos de checagem em todas as etapas do ciclo celular. O processo de controle é complexo e envolve a checagem de inúmeras moléculas com potencial para estimular e/ou inibir a proliferação. Dentre as moléculas que controlam o ciclo celular, destacam-se duas proteínas conhecidas como as principais responsáveis na progressão das fases do ciclo celular. São essas, as Cdks (do inglês: Cyclin Dependent Kinases) e as ciclinas. As Cdks são membros da família das proteínasquinases, moléculas com capacidade para fosforilar substratos específicos quando ativadas por sua proteína ligante específica (ciclina). As ciclinas são proteínas envolvidas no controle do ciclo celular, que têm como característica ciclos de acúmulo e degradação. O acúmulo de ciclinas na célula ativa a família das Cdks desencadeando uma cascata de sinalização essencial para que as células avancem nas etapas do ciclo celular (SPENCER et al., 2013; STILLMAN, 1996). Cada fase do ciclo envolve a ligação de ciclina/Cdk específicas. Para que uma célula deixe o estado de quiescência, faz-se necessário que as ciclinas do tipo D se associam com as Cdks 4/6. A superação do ponto de restrição (G1/S) é controlada pela ligação entre Ciclinas $E$ com a Cdks 2. A progressão de $S$ para $G 2$ é controlada pelas Ciclinas A e Cdk 2 enquanto a mitose depende da associação das ciclinas $B$ com a Cdk1 (FAVARO et al., 2013). As proteínas envolvidas na inibição do ciclo celular são denominadas de CKIs (do inglês: Cyclin Dependent Kinase Inhibitors) cuja denominação decorre de sua capacidade de inibir a ligação da ciclina à sua Cdk alvo, inbição essa, que impossibilita a progressão do ciclo celular. As proteínas p21 e p27 são exemplos de CKls capazes de inibir a ligação das ciclinas D com as Cdks 4/6. Para que a célula saia do estado de quiescência essas proteínas devem sofrer degradação (COATS et al., 1996). Outras importantes CKI atuam no controle de danos sofridos pelo DNA (fase G2). Um exemplo é a proteína p53 considerada a molécula guardiã, que impede a mitose em células com defeitos no DNA. De fato, 
grande parte das disfunções proliferativas decorrem de defeitos na funcionalidade dessa proteína (ELLEDGE, 1996; KRENNING et al., 2014). Em resumo, o balanço de proteínas pró-proliferação e anti-proliferação é vital para evitar defeitos na proliferação dos órgãos de organismos adultos.

\subsubsection{Controle hormonal da proliferação celular}

O papel dos hormônios E2 e P4 sobre a proliferação celular dos compartimentos uterinos são amplamente descritos. No endométrio, o E2 promove a proliferação dos epitélios enquanto a P4 bloqueia essa proliferação ao mesmo tempo em que estimula a proliferação das células do estroma. As células do miométrio são estimuladas pela ação conjunta de E2 e P4. Na ausência da P4 ocorre a interrupção do ciclo celular das células do estroma uterino (CULLINGFORD; POLLARD, 1988; RIDER; PSYCHOYOS, 1994), sugerindo que a P4 exerce um controle sobre a maquinaria que regula o ciclo celular. A P4 atua tanto diretamente na expressão de proteínas que controlam o ciclo celular, como por intermédio do PR que ativa fatores de crescimento (RIDER, 2002) figura 5. Estudos mostraram, que a P4 estimula a expressão de proteínas ativadoras do ciclo celular tais como as ciclinas D1 e D3 (JONES et al., 2000; SUTHERLAND et al., 1998). O PR também interage com fatores de crescimento como o FGF (do inglês: fibroblast growth factor) e IGF-1 (JONES et al., 2000; ZHU; POLLARD, 2007). Fatores de transcrição também são modulados pela P4; um exemplo é o Hoxa-10 que controla o estimulo proliferativo dos fibroblastos endometriais. Estudos com animais deficientes para 0 Hoxa-10 apresentam uma resposta proliferativa deficiente, levando ao desenvolvimento de dificuldades para implantar o embrião e até infertilidade (LIM et al., 1999; YUE et al., 2005). Adicionalmente, os PRs inibem moléculas capazes de parar o ciclo celular, entre elas p21 e p27 (JONES et al., 2000; LABAER et al., 1997). Em conjunto, a sinalização por P4 e E2 promove a saída da quiescência e, consequentemente, a progressão do ciclo celular. Neste contexto, alterações na ação dos hormônios E2 e P4 pode comprometer a proliferação celular e, consequentemente, o desenvolvimento de alterações reprodutivas. 


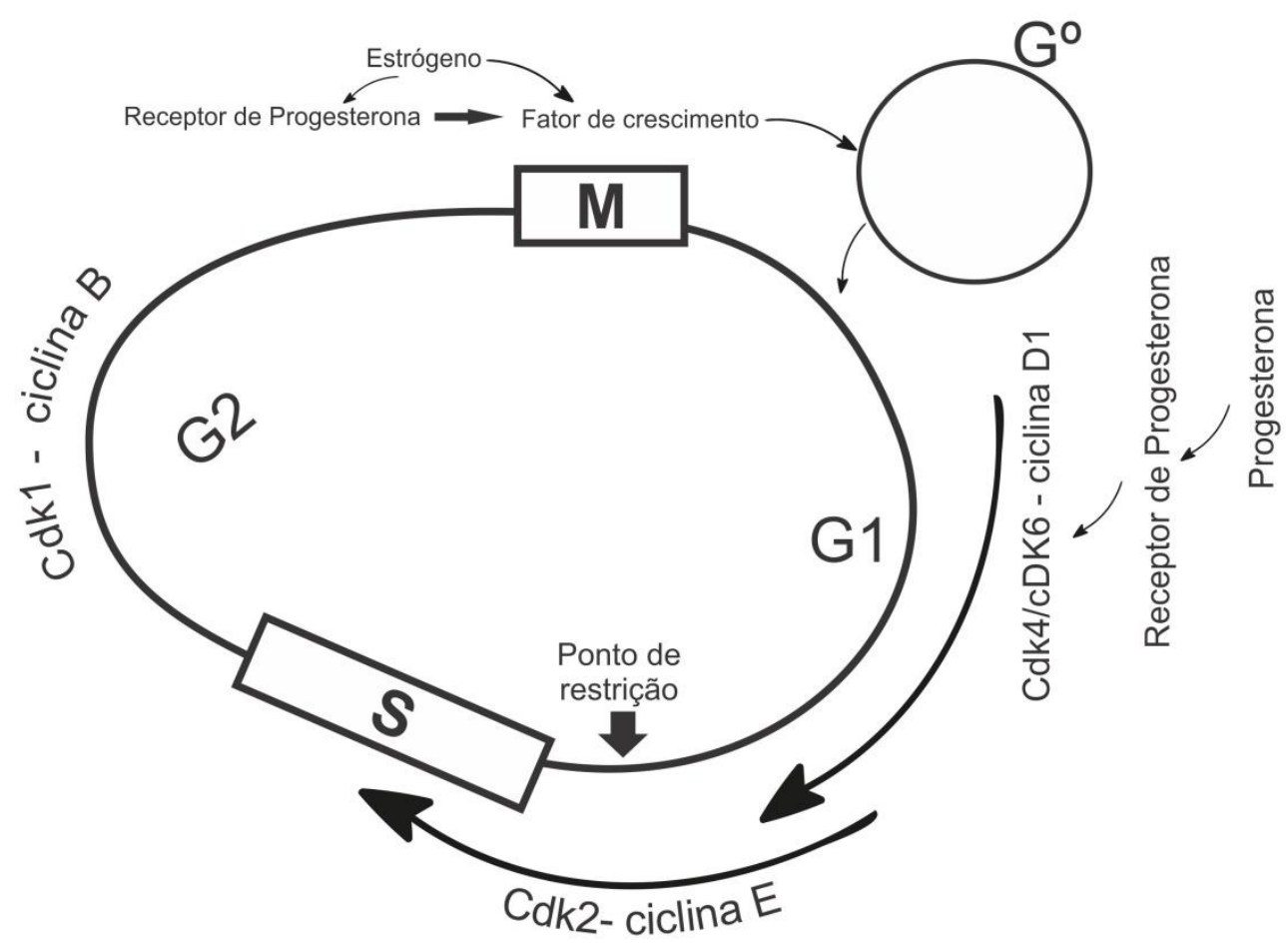

Figura 5. Esquema destaca: i) as principais fases do ciclo celular e as proteínas reguladoras. ii) $O$ controle da progesterona na proliferação das células estromais uterinas (adaptado de: RIDER, 2002).

\subsection{Diabetes mellitus}

\subsubsection{Epidemiologia}

Em 1985 estimava-se haver cerca de 30 milhões de adultos com Diabetes mellitus (DM) no mundo. Este número cresceu para cerca de 135 milhões em 1995, atingindo 173 milhões em 2002 com projeção de chegar a 300 milhões em 2030. Os dados da Organização Mundial da Saúde (2012) revelaram a prevalência do DM em $9 \%$ dos adultos maiores de 18 anos. Além disso, estimaram, que mais de 1,5 milhões de mortes são causadas pelo DM. Sabe-se ainda, que mais de $80 \%$ das mortes por DM ocorrem em países em desenvolvimento, onde politicas publicas de prevenção e tratamento (controles glicêmicos) da população são menos eficientes. A projeção é que o DM possa vir a ocupar a $7^{a}$ posição no ranking de causa de morte no mundo. Os custos diretos aos cofres públicos da prevenção e tratamento podem variar de $2,5 \%$ a $15 \%$ do orçamento anual para a saúde (ORGANIZAÇÃO MUNDIAL DE SAÚDE, 2012). 


\subsubsection{Tipos de diabetes mellitus}

O DM é caracterizado por um conjunto de doenças metabólicas, que apresentam como característica comum, níveis elevados de glicose no sangue (hiperglicemia), em consequência da ação e/ou produção deficiente de insulina pelo organismo. As principais formas de diabetes são as do tipo 1, tipo 2 e gestacional. 0 DM do tipo 1 (DM1) é caracterizado pela ausência na produção de insulina, ocasionada pela destruição das células- $\beta$ pancreáticas, por um processo mediado pelo sistema imunológico. 0 DM do tipo 2 decorre da combinação de múltiplas alterações na homeostase da glicose causando resistência insulínica, resposta compensatória na secreção de insulina e/ou defeitos na secreção da insulina, além de anormalidades na captação e excreção da glicose. Sabe-se que 80 a $90 \%$ dos casos de DM são do tipo 2. Além disso, existe o DM gestacional que apresenta efeitos semelhantes ao DM do tipo 2, e ocorre no primeiro trimestre da gestação devido uma diminuição na sensibilidade à insulina. Trata-se de uma estratégia do organismo para levar os nutrientes, preferencialmente, para o feto em desenvolvimento (DEFRONZO, 2004; FREINKEL, 1980).

\subsubsection{Diabetes e gestação}

Antes do advento da insulina a coexistência de DM e gestação, era extremamente rara (ROSENFELD, 2013). Os avanços clínicos na utilização da insulina e nos tratamentos para o DM proporcionaram uma grande melhora nas taxas de mortalidade materna e perinatal de portadoras de diabetes (ENGELGAU et al., 1995). Estudos populacionais tem demostrado que a prevalência de gestação associada ao DM é de 4\% - 13\% (HAPO, 2010; SCHULLER, 2007; METZGER et al., 2008). Entretanto, a incidência de gestantes portadoras do DM1 chega a $\pm 1 \%$. (JENSEN et al., 2004). O descontrole glicêmico durante a gravidez aumenta em até 4 vezes as complicações durante o desenvolvimento da gestação (IVANISEVIC et al., 1999). Estudos clínicos revelam que o DM1 está diretamente associado a elevadas taxas de abortos, malformações congênitas, restrição do crescimento intrauterino e parto prematuro (CASSON et al., 1997; LAPOLLA et al., 2008). Os fatores sistêmicos do DM1 como a hiperglicemia e hipoinsulenemia prejudicam o desenvolvimento do embrião, devido ao comprometimento do ambiente uterino 
(OTANI et al., 1991). Além disso, sabe-se, que a interface materna da gestante portadora de DM1 produz maior quantidade de fatores pró-inflamatórios tais como espécies reativas de oxigênio, citocinas e prostaglandinas, óxido nítrico e peroxinitritos. Essa interface materno-fetal alterada representa um desafio para o desenvolvimento adequado da gestação (JAWERBAUM; GONZALEZ, 2006; RADAELLI et al., 2003).

No ambiente uterino, E2 e P4 são os reguladores de todas as respostas durante o ciclo reprodutivo e a gestação. Garris, Whitehead e Morgan (1984), demonstraram que DM1 também impacta a gravidez por reduzir os níveis séricos da $\mathrm{P} 4$. A redução da produção da $\mathrm{P} 4$ durante a gestação é relacionado a complicações na angiogênese uterina (GARRIS, 1988; KIM et al., 2013). Além do mais, fêmeas de camundongos NOD (do inglês: non-obese diabetic mice) apresentaram interrupção do ciclo estral, associado com diminuição do peso uterino e atrofia do endométrio e do miométrio (TATEWAKI et al., 1989). Kienast e colaboradores (1993) reforçam estes dados correlacionando os efeitos prejudiciais do DM1 no eixo hipotálamohipófise. De fato, esses animais a secreção do LH é prejudicada, resultando em alterações na sinalização para a produção de E2 e P4 pelas células ovarianas. Adicionalmente, estudos in vitro utilizando células da granulosa ovariana demonstram que altas concentrações de glicose prejudicam a produção de E2 e P4. Da mesma forma, estudos em modelos experimentais in vivo mostram diminuição nos níveis séricos desses hormônios e aumento de testosterona. Essas alterações hormonais promovem o prolongamento do ciclo estral e/ou a entrada em anestro destes animais (CHABROLLE et al., 2008; GRIFFIN et al., 1994; KIM et al., 2006). Entretanto, os dados existentes na literatura apenas associam a doença a reduções dos níveis dos hormônios ovarianos, e nada se sabe a respeito do impacto do DM na sinalização destes hormônios por meio de seus receptores e/ou em suas vias de sinalização. 
1.6.4 Contribuições do LBR \& MEC em modelo de diabetes tipo 1 e gestação

Diante do contexto descrito nos tópicos anteriores e com o objetivo de contribuir com estudos sobre o tema DM1 e reprodução, o LBR \& MEC desenvolveu um modelo experimental de DM1 em fêmeas de camundongos. O modelo se caracteriza por apresentar um perfil fisiopatológico semelhante ao encontrado em pacientes com DM1, que inclui: I) altas concentrações de glicose sanguínea ( $>400$ $\mathrm{mg} / \mathrm{dL})$; ii) hipoinsulinemia; iii) glicosúria; iv) aumento do consumo de alimentos e de água; v) redução do peso corporal (FAVARO et al., 2015; FAVARO et al., 2013; FAVARO et al., 2010). Entre os diferenciais deste modelo destaca-se a possibilidade de se investigar animais com altos valores glicêmicos, em diferentes períodos de duração do diabetes (i.e. estágios de progressão da doença). Destaca-se que nesse modelo não há reposição de insulina o que descarta possível mascaramento de desenvolvimento de complicações.

Dentre os principais resultados obtidos pelo nosso grupo destaca-se a constatação de que o DM1 promove alterações importantes na MEC do miométrio, endométrio e placenta. Viu-se ainda que os efeitos são dependentes do tempo de exposição ao DM1. No miométrio, a DM1 promove alterações na citoarquitetura, e na organização do sistema contráctil. Em adição, houve redução da espessura das camadas musculares correlacionada com diminuição da proliferação das células musculares lisas dessa estrutura (FAVARO et al., 2015; FAVARO et al., 2010). Em outro estudo utilizando esse modelo de DM1, constatou-se que a diabetes promove diminuição da área de decidualização do endométrio em conjunto com alterações na remodelação da MEC decidual (FAVARO et al., 2013). Estudos de outros grupos correlacionaram o comprometimento da decidualização com alterações nos níveis dos hormônios ovarianos E2 e P4 (ZAKARIA et al., 2000). Adicionalmente, foi demonstrada por radioautografia, a diminuição da fração citoplasmática e nuclear dos ER em células decidualizadas do endométrio de ratas DM (DE HERTOGH et al., 1989).

Portanto, considerando o papel fundamental dos hormônios esteroides ovarianos para a fisiologia uterina, incluindo a proliferação celular e remodelação da MEC, nossa hipótese é que algumas das complicações promovidas pelo DM nestes processos possam estar associadas à alterações na sinalização hormonal. 
Ressalta-se, que embora existam evidências de que o DM comprometa a sinalização do E2 no ambiente uterino, os efeitos dessa doença sobre a ação da P4 ainda não haviam sido investigados em nenhum órgão. É importante ainda enfatizar, que coexistem, nas fêmeas diabéticas, alterações nos níveis hormonais circulantes como é o caso da ação dos hormônios nos tecidos. Neste contexto, o presente trabalho busca contribuir com novos resultados que ampliem o entendimento do impacto do diabetes na sinalização da P4 no ambiente uterino. 
2 OBJETIVO 
Resultados prévios obtidos pelo nosso grupo de pesquisa demostraram, que o diabetes mellitus do tipo 1 altera processos biológicos controlados pela progesterona tais como a proliferação celular e a remodelação da matriz extracelular nos tecidos uterinos de camundongos (FAVARO et al., 2013; SALGADO et al., 2011). Diante disso e visando a aprofundar nosso entendimento sobre esse importante tema, a proposta do presente estudo é verificar a hipótese de que o diabetes mellitus do tipo 1 interfere na resposta proliferativa no ambiente uterino estimulada pela progesterona, promovendo alterações no processo de estabelecimento da gestação e, também, no desenvolvimento de complicações gestacionais.

\subsection{Objetivo geral}

Investigar a responsividade dos tecidos uterinos à estimulação pela progesterona em um modelo de diabetes mellitus do tipo 1 submetido à castração e reposição hormonal.

\subsection{Objetivos específicos}

1) Viabilizar, nesse modelo de diabetes mellitus do tipo 1, a execução dos procedimentos cirúrgicos e a exposição dos animais diabéticos ao protocolo de reposição hormonal;

2) Estabelecer um protocolo de reposição hormonal, que mimetize a resposta proliferativa promovida pela progesterona;

3) Averiguar o impacto do diabetes sobre o endométrio uterino e a proliferação das células estromais uterinas;

4) Avaliar o impacto do diabetes sobre os receptores de progesterona.

5) Investigar os efeitos do diabetes em genes envolvidos na proliferação das células estromais uterinas controlados pela progesterona. 
Todos os procedimentos foram aprovados pelo Comitê de Ética e Experimentação Animal do Instituto de Ciências Biomédicas da Universidade de São Paulo (Protocolo no 125, Folha 12,Livro 3).

\subsection{Animais e sua manutenção}

Para este estudo foram utilizadas fêmeas de camundongos da linhagem Swiss, sexualmente maduras (3-4 meses de idade) provenientes do biotério do Departamento de Farmacologia - ICB/USP. Os animais foram alojados no biotério do Departamento de Biologia Celular e do Desenvolvimento - ICB/USP em ambiente com temperatura controlada $\left(22^{\circ} \mathrm{C}\right)$, com livre acesso à ração e água em um regime de 12h:12-h (horas) luz-escuro. Visando a minimizar a interferência, nos experimentos, de compostos com ação hormonal provenientes da dieta, as fêmeas foram alimentadas desde o desmame, com ração com baixos teores de fitoesteroides (Rhoster, São Paulo, Brasil).

\subsection{Indução do Diabetes}

O diabetes foi induzido de acordo com o protocolo estabelecido por Favaro e colaboradores (2013). Após serem privadas de alimento por $16 \mathrm{~h}$, as fêmeas receberam uma única administração i.v (intravenosa) pela veia caudal, de $40 \mathrm{mg} / \mathrm{Kg}$ de aloxana (Sigma-Aldrich, St Louis, USA), diluída em solução salina (ph 7,0). As fêmeas controles receberam apenas solução salina. Para prover vasodilatação e facilitar a injeção da aloxana, a veia caudal foi recoberta com uma gaze umedecida com água levemente aquecida. Após quatro dias da indução, os níveis de glicemia foram verificados utilizando glicosimetro Accu-check Performa ${ }^{\circledR}$ (Roche diagnostic, Basel, Suiça). As fêmeas com glicemia $>400 \mathrm{mg} / \mathrm{dL}$ foram selecionadas para 0 estudo. A avaliação da glicosúria foi realizada utilizando fitas de teste KetoDiaburTest ${ }^{\circledR}$ (Roche). 


\subsection{Ovarectomia}

Os procedimentos cirúrgicos seguiram os protocolos já estabelecidos no LBR \& MEC. Inicialmente, as fêmeas foram anestesiadas por meio de injeção intraperitoneal (i.p) com $0,025 \mathrm{~g} / \mathrm{mL}$ de tribromo-etanol (Avertin®). O procedimento cirúrgico de remoção bilateral dos ovários foi realizado por meio de uma pequena incisão dorsal, que permitiu a localização e exposição dos cornos uterinos. Em seguida, foram realizadas duas incisões na musculatura das regiões dorsais próximas aos ovários. Para evitar uma possível hemorragia realizou-se a ligadura na junção útero tubária de cada corno uterino e, em seguida, foram removidos os ovários. Após os procedimentos, o músculo e a pele foram suturados. Por fim, realizou-se a assepsia da região operada e o animal foi mantido em observação por $24 \mathrm{~h}$. Após a cirurgia, os animais receberam dipirona sódica $(0,01 \%)$ na água dos bebedouros para evitar dor e desconfortos pós-operatórios. A limpeza das gaiolas foram realizadas diariamente até a recuperação dos animais.

\subsection{Esfregaço Vaginal e Coloração de Shorr}

A eficácia da ovarectomia foi confirmada por meio de análise citológica de esfregaços vaginais corados pelo método de Shorr (1941). As amostras foram coletadas em duas etapas: i) 4 dias antes da ovarectomia; ii) 7 dias após a ovarectomia. Em cada uma das etapas as amostras foram coletadas por dois dias consecutivos.

A coleta do material vaginal foi realizada com o auxilio de uma escova muito fina embebida em solução salina. A escova era introduzida gentilmente na vagina do animal e submetida a leves movimentos rotacionais e, em seguida, deslizada sobre a superfície de uma lâmina histológica de vidro. As lâminas foram deixadas para secar por 15 minutos em T.A (temperatura ambiente) e, posteriormente imersas em uma solução fixadora de etanol 70\% - éter (1:1) por 10 minutos. Após a fixação, as lâminas foram submetidas à coloração pelo corante de Shorr de acordo com os seguintes passos: (i) imersão em etanol 70\% (02 minutos); (ii) lavagem em H2Od (dois minutos); iii) coloração por hematoxilina de Harris (cinco minutos); (iv) lavagem em H2O corrente (10 minutos) seguida de H2Od (02 minutos); (v) desidratação em 
série crescentes de etanol 70\% (02 minutos), 80\% (02 minutos) (vi) coloração pelo corante de Shorr (10 minutos - sob agitação); (vii) desidratação: etanol 95\% (2 minutos); etanol absoluto (10 minutos) e (viii) diafanização por em xilol (10 minutos). Finalmente, as lâminas foram cobertas com goma de Damar (Sigma) e lamínula para posterior análise.

\subsection{Reposição Hormonal}

O tratamento hormonal foi iniciado vinte dias após a ovarectomia (OVX), de acordo com o protocolo utilizado por Martin e Finn (1968). Este protocolo promove um perfil hormonal similar aquele dos primeiros dias da gestação, período em que ocorre a proliferação dos fibroblastos endometriais, alvo desse estudo. Inicialmente as fêmeas foram expostas a uma única dose s.c (subcutâneo) de $1 \mu \mathrm{g}$ de $17 \beta$ estradiol (Sigma), seguida por $24 \mathrm{~h}$ de descanso e quatro doses de $1 \mathrm{mg}$ de progesterona (Sigma) administradas a cada $24 \mathrm{~h}$. Os hormônios foram diluídos em óleo de milho. As amostras foram coletadas $24 \mathrm{~h}$ após a última administração de progesterona. O protocolo da administração hormonal está explicitado na Figura 6. O grupo controle foi formado por fêmeas não submetidas à reposição hormonal, que receberam apenas injeções dos veículos empregados nas diluições dos hormônios. Para o estudo foram constituídos quatro grupos experimentais:

1) OVX-Controle: fêmeas normoglicêmicas, ovarectomizadas, sem tratamento hormonal;

2) OVX-DM: fêmeas diabéticas, ovarectomizadas, sem tratamento hormonal;

3) P4-Controle: fêmeas normoglicêmicas, ovarectomizadas e submetidas a reposição pela progesterona;

4) P4-DM: fêmeas diabéticas, ovarectomizadas e submetidas à reposição pela progesterona; 


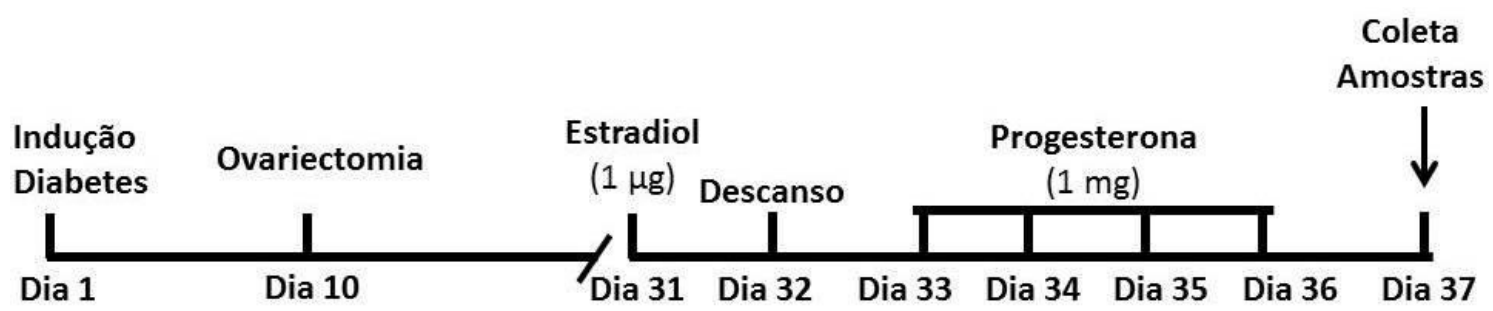

Figura 6. Protocolo de reposição hormonal. As fêmeas de camundongos foram ovarectomizadas 10 dias após a indução do diabetes e a reposição hormonal foi iniciada 20 dias após a ovarectomia. Inicialmente, foi administrada uma dose de sensibilização de estradiol (1 ug), e após $48 \mathrm{~h}$ foram administradas 4 doses de progesterona $(1 \mathrm{mg})$ com intervalos de $24 \mathrm{~h}$. Os tecidos uterinos foram coletados para análise $24 \mathrm{~h}$ após a última dose de progesterona.

\subsection{Coleta e processamento das amostras}

Para o procedimento de coleta os animais foram profundamente anestesiados por Avertin® (Sigma). Realizou-se uma secção ventral para exposição dos cornos uterinos. Para evitar a contração do miométrio gotejou-se a solução de papaverina $4 \%$ (diluído em salina) sobre os mesmos antes da remoção. Após a remoção, os cornos uterinos foram separados para as análises de morfologia e biologia molecular. As amostras destinadas aos estudos morfológicos foram fixadas por $3 \mathrm{~h}$ à T.A. em Methacarn (álcool absoluto, clorofórmio, ácido acético glacial; 6:3:1), lavadas em álcool absoluto e incluídas em Paraplast ${ }^{\circledR}$ (Merck Millipore, Darmstadt, Alemanha). Dessas amostras, foram obtidos cortes com espessura de $5 \mu \mathrm{m}$, os quais foram aderidos à lâminas de vidro recobertas com poly-L-lysine (Sigma). As amostras destinadas às análises moleculares e bioquímicas foram conservadas em RNA later (Sigma) para posterior análise pela PCR quantitativa em tempo real (qPCR) ou em tampão de lise adicionado de coquetel inibidor de proteases (Sigma), para as análises de Western blotting.

\subsection{Histomorfometria}

As dimensões do endométrio foram avaliadas em cortes transversais dos cornos uterinos corados por Picrosirius-hematoxilina (Apêndice). As mensurações foram realizadas em amostras de cinco animais de cada um dos grupos 
experimentais. Para cada animal foram aferidos três cortes histológicos com distâncias de 100 a $150 \mu \mathrm{m}$ entre eles. As análises histomorfométricas foram realizadas em imagens capturadas de um microscópio Nikon Eclipse E600, integrado a uma câmera digital DP72 (Olympus, Tóquio, Japão), utilizando o software ImagePro-Plus (Media Cybernetics, Rockville, USA). A área do estroma endometrial foi calculada pela subtração da área do endométrio total daquela ocupada pelos epitélios luminal e glandular.

\subsection{Imunolocalizaçãode PCNA e Receptor de Progesterona (PR)}

Após a desparafinização e hidratação, as amostras foram lavadas em tampão fosfato salino (PBS). Para a recuperação antigênica, utilizou-se tampão citrato $\mathrm{pH}$ 6,0 por 12 minutos a $98{ }^{\circ} \mathrm{C}$ para o anticorpo anti-PR ou tampão Tris $\mathrm{pH} 9,0$ para $\circ$ anticorpo anti-PCNA. O bloqueio da peroxidase endógena foi realizado por $3 \%$ de H2O2 (Merck Millipore) e o bloqueio dos sítios antigênicos inespecíficos, pela incubação com soro do doador do anticorpo secundário, adicionado de PBS/BSA 5\% (1:1) por $1 \mathrm{~h}$. No controle-negativo foi omitido o anticorpo primário. Os anticorpos primários antipoliclonal (coelho) anti-PR (1:200; Santa Cruz Biotechnology, Dallas, EUA) e anti-PCNA policlonal (coelho) (1:1000; Abcam, Cambridge, Inglaterra) foram incubados overnigh e a $4 \stackrel{\circ}{\circ}$. Para a reação do PCNA foi empregado um anticorpo secundário anti-lgG de coelho produzido em cabra, conjugado com peroxidase (Rockland, Limerick, USA) por $1 \mathrm{~h}$. A revelação da reação foi realizada durante 40 segundos pela 3,3-diaminobenzidina (DAB) (Sigma) 0,03\% em PBS e H2O2 0,03\%. Os preparados histológicos então foram contra-corados pela hematoxilina. Para a Imunolocalizaçãodo PR utilizou-se um anticorpo secundário conjugado com Alexa 594 (Invitrogen, Nova lorque, USA), por $1 \mathrm{~h}$. Os núcleos foram contra-corados com DAPI (KPL, Gaithersburg, USA) por 15 minutos e as lâminas montadas com meio montagem especial que preserva a fluorescência (KPL, USA).

\subsection{Western blotting}

As frações proteicas do núcleo e citoplasma foram obtidas utilizando-se o kit Nuclear and cytoplasmic extraction reagents-NE-PER (Thermo Scientific, Nova lorque, USA), de acordo com o protocolo recomendado pelo fabricante. A 
concentração protéica dos lisados foi determinada pelo método colorimétrico de Bradford, 1976 (Sigma). As amostras foram ressuspendidas em tampão de amostra contendo $3 \%$ de dodecil sulfato de sódio (SDS), $150 \mathrm{mM}$ Tris pH $6.8,15 \%$ de mercaptoetanol, $30 \%$ de glicerol e $0,01 \%$ de azul de bromofenole e fervido por 5 minutos. A eletroforese para separação das proteínas foi realizada pelo método de SDS-PAGE, em gel contendo $10 \%$ de poliacrilamida. Em seguida, as proteínas do gel foram transferidas para membranas de nitrocelulose (GE Healthcare, Pittsburgh, USA). As membranas foram lavadas em TBS-Tween (100mM de $\mathrm{NaCl}, 10 \mathrm{mM}$ de Tris-HCl pH 8,0 e 0,05\% de Tween-20) e incubadas por $1 \mathrm{~h}$ em tampão de bloqueio (TBS-Tween acrescido de 4\% de BSA (p/v) (Sigma) ou 5\% de Leite Molico (Nestlé, São Paulo, Brasil). Subsequentemente, as membranas foram incubadas overnight com os anticorpos primários: anti-PR policlonal de coelho (1:500; Santa Cruz), anticorpo anti-Lamina B1 policlonal de coelho (1:1000; Abcam) ou anti- $\beta$-actina monoclonal de camundongo (1:500; Santa Cruz). Após a incubação dos anticorpos primários, as membranas foram lavadas por cinco vezes com TBS-Tween. De acordo com o anticorpo primário, as membranas foram então incubadas com os anticorpos secundários anti-lgG de coelho (feito em burro) ou anti-lgG de camundongo (feito em burro) (Jackson ImmunoResearch, West Grove, USA) conjugados com HRP, na concentração de 1:20000, por 30 minutos. Logo após a incubação com os anticorpos secundários, as membranas foram lavadas por 10 vezes com TBS/Tween e, em seguida reveladas por quimioluminescência em kit ECL (BioRad, California, USA). A leitura da reação foi feita em um fotodocumentador Amersham Imager 600 (GE). As quantificações das bandas foram realizadas pela medida da mediana da densidade óptica utilizando-se o software Adobe Photoshop 7.0 (Adobe Systems, Califórnia, USA).

\subsection{Análise da expressão do RNAm pela PCR quantitativa em tempo real}

Após a homogenização das amostras uterinas em um homogenizador (Precellys, Bertin, França), o RNA total foi extraído utilizando-se o kit llustraRNAspin Mini (GE), conforme instruções do fabricante. A síntese do cDNA foi realizada utilizando-se $1 \mu \mathrm{g}$ do RNA total de cada amostra, random primers e o Superscript III Supermix (Invitrogen). A reação da $\mathrm{QPCR}$ foi realizada em um volume total de $25 \mu \mathrm{l}$ por amostra, contendo o cDNA, os primers para a PR-B, PR A+B, Ciclina D1, E1, 
p27, FGF2 e Hoxa 10 (Tabela 1) e SYBR Green qPCR Master Mix (Life Technologies, Califórnia, USA). Foram testados GAPDH, Ywhaz, 18srRNA, Rpl7 e HPRT como genes de referência para a análise dos resultados, e o escolhido foi o HPRT. A quantificação relativa da expressão gênica foi determinada pelo método de 2- $\triangle \triangle$ Ct (LIVAK; SCHMITTGEN, 2001).

Tabela 1. Primers de camundongos $\left(5^{\prime} \rightarrow 3^{\prime}\right)$

\begin{tabular}{|c|c|c|c|}
\hline Gene & Forward e Reverse & $\begin{array}{l}\text { Tamanho } \\
\text { Amplicon }\end{array}$ & Genbank\# \\
\hline Ciclina D1 & $\begin{array}{l}\text { F: GGGTGGGTTGGAAATGAAC } \\
\text { R: TCCTCTCCAAAATGCCAGAG }\end{array}$ & $110 \mathrm{pb}$ & NM 007631.2 \\
\hline Ciclina E1 & $\begin{array}{l}\text { F: CTCGGGTGTTGTAGGTTGCT } \\
\text { R:CTGTTGGCTGACAGTGGAGA }\end{array}$ & $112 \mathrm{pb}$ & NM 007633.2 \\
\hline p27 & $\begin{array}{l}\text { F: TTCTTCTGTTCTGTTGGCCC } \\
\text { R: GTGGACCAAATGCCTGACTC }\end{array}$ & $126 \mathrm{pb}$ & NM 009875.4 \\
\hline Hoxa 10 & $\begin{array}{l}\text { F: TTCGCCGGAGAAGGACTC } \\
\text { R: TCTTTGCTGTGAGCCAGTTG }\end{array}$ & $68 p b$ & NM 008263.3 \\
\hline FGF2 & $\begin{array}{l}\text { F: GCGACCCACACGTCAAACTA } \\
\text { R: TCCCTTGATAGACACAACTCCTC }\end{array}$ & $62 p b$ & NM 008006.2 \\
\hline Gapdh & $\begin{array}{l}\text { F: TCTGAGGGCCCACTGAAG } \\
\text { R: AGGGTTTCTTACTCCTTGGAGG }\end{array}$ & $221 \mathrm{pb}$ & $\begin{array}{l}\text { NM } 001289726 \\
.1\end{array}$ \\
\hline HPRT & $\begin{array}{l}\text { F: GCTGACCTGCTGGATTACAT } \\
\text { R: CAATCAAGACATTCTTTCCAGT }\end{array}$ & $172 \mathrm{pb}$ & NM 013556.2 \\
\hline Rpl7 & $\begin{array}{l}\text { F: GCAGATGTACCGCACTGAGATTC } \\
\text { R: ACCTTTGGGCTTA CTCCATTGATA }\end{array}$ & 129pb & NM 011291.5 \\
\hline Ywhaz & $\begin{array}{l}\text { F: GAAGCCACAATGTTCTTGGCCCAT } \\
\text { R: AAACCAACAGAGACTTGGAAGCAC }\end{array}$ & $84 \mathrm{pb}$ & $\begin{array}{l}\text { NM } 001253806 \\
.1\end{array}$ \\
\hline 18SrRNA & $\begin{array}{l}\text { F: GTAACCCGTTGAACCCCATT } \\
\text { R: CCATCCAATCGGTAGTAGCG }\end{array}$ & $151 \mathrm{pb}$ & NC 000083.6 \\
\hline
\end{tabular}

\subsection{Dosagem hormonal sérica em Multiplex}

As amostras foram coletadas em tubos estéreis de $1,5 \mathrm{ml}$ e deixadas a T.A para coagulação. Em seguida, as amostras foram centrifugadas a $11000 \mathrm{rpm}$ por 20 minutos a $4{ }^{\circ} \mathrm{C}$. $\mathrm{O}$ soro foi imediatamente separado e congelado a $-20{ }^{\circ} \mathrm{C}$. Para a dosagem hormonal de estrógeno e progesterona, foi utilizado o kit MILLIPLEX 
(Merck Millipore) e, para a leitura das placas foi utilizado o luminex BIO-plex200 (Biorad). As microesferas revestidas com anticorpos monoclonais contra os alvos (progesterona e estrógeno) foram adicionadas aos poços. As microesferas possuem cores distintas que identificam os diferentes biomarcadores enquanto a ficoeritrina serve como um indicador fluorescente para determinação da concentração. As amostras e padrões (variando de 0,1 a $10.000 \mathrm{pg} / \mathrm{mL}$ para cada análise) foram pipetados nos poços e incubados overnight a $4 \stackrel{\circ}{\mathrm{C}}$. Os poços foram lavados e aspirados com lavadora magnética Bio-plex PRO II Wash Station (Bio-rad) na qual as microesferas ficam retidas na placa pela ação de um imã. Após lavagem, uma mistura de anticorpos biotinilados secundários foram adicionados e incubados. A estreptavidina conjugada com a proteína fluorescente, R-ficoeritrina (estreptavidina$\mathrm{RPE}$ ) foi adicionada e incubada por 1h a T.A. Após a lavagem para remoção dos reagentes não aderidos, adicionou-se aos poços uma solução tampão (Luminex®, MiraiBio, Alameda, USA) para serem analisadas no analisador de microesferas (Bioplex 200). As concentrações das amostras desconhecidas (antígenos nas amostras de soro) foram estimadas a partir da curva padrão, utilizando o Bio-Plex Manager Software (Bio-Rad). Os níveis dos hormônios foram expressos em ng / mL.

\subsection{Análises Estatísticas}

As análises estatísticas dos dados foram obtidas pelo software GraphPad (GraphPad Software, La Jolla, USA) utilizando o ANOVA, seguido do pós-teste Tukey, para comparações múltiplas $(p \leq 0,05)$. 
4 RESULTADOS 


\subsection{Indução da Diabetes Mellitus tipo1}

A indução do DM foi realizada farmacologicamente por meio de injeção de Aloxana®. A eficiência obtida por esse procedimento foi $65 \%$ á $73 \%$, valores que se encontram dentro dos padrões relatados para esta droga.

\subsection{Ovarectomia e Reposição Hormonal}

Constatou-se que os animais DM1 resistem ao procedimento cirúrgico de OVX visto que, os índices de ocorrência de morte pós-cirúrgica foram semelhante em ambos os grupos normoglicêmicos e diabéticos. Nesse estudo, utilizou-se 48 animais normoglicêmicos, tendo sido registradas 2 mortes pós-cirúrgica $(4,16 \%)$. Para grupos diabéticos utilizou-se 56 animais e registrou-se apenas 3 mortes póscirúrgica (5,35\%). Adicionalmente, não houve a ocorrência de morte de animais durante o procedimento de reposição hormonal. Esses dados nos permite concluir que o nosso modelo de indução de DM1 - OVX - reposição hormonal é, do ponto de vida experimental, viável.

\subsection{Eficiência da Ovarectomia}

A garantia da eficiência da OVX foi confirmada por meio da citologia em esfregaços vaginal. As amostras coletadas antes da OVX apresentaram características morfológicas típicas de cíclicidade, demonstrando as quatro fases do ciclo estral: estro caracterizado pelo grande número de células superficiais cornificadas (Figura 7-A); metaestro caracterizado por grande número de células cornificadas com acumulo de leucócitos polimorfonucleres (Figura 7-B); diestro caracterizado pela presença de muco, leucócitos polimorfonucleres e de poucas células basais (Figura 7-C); e proestro contendo poucas células basais e algumas da camada intermediária (Figura 7-D). Adicionalmente, as amostras coletadas 7-8 dias após a OVX confirmaram a eficiência da castração isto é: todas as fêmeas apresentarem um único padrão citológico no esfregaço vaginal, conhecido como estado de anestro. $O$ anestro apresenta características citológicas semelhantes ao diestro, porém, torna-se permanente ao longo do tempo (Figura 7-E,F). 

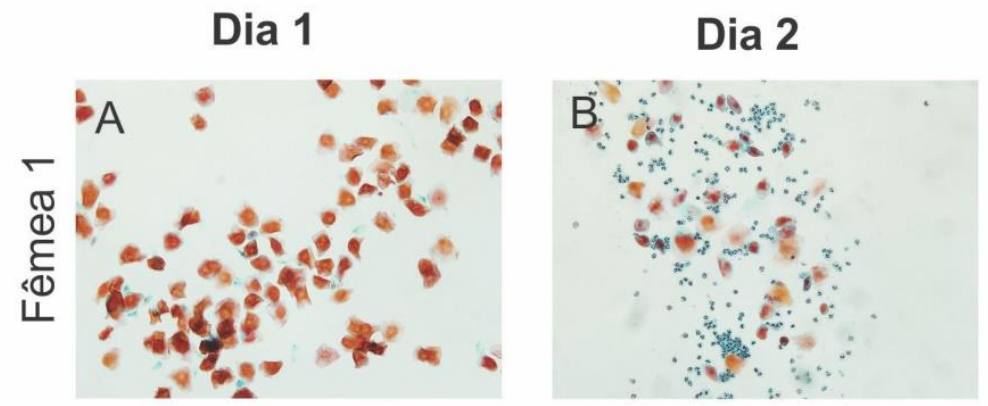

\section{Antes OVX}
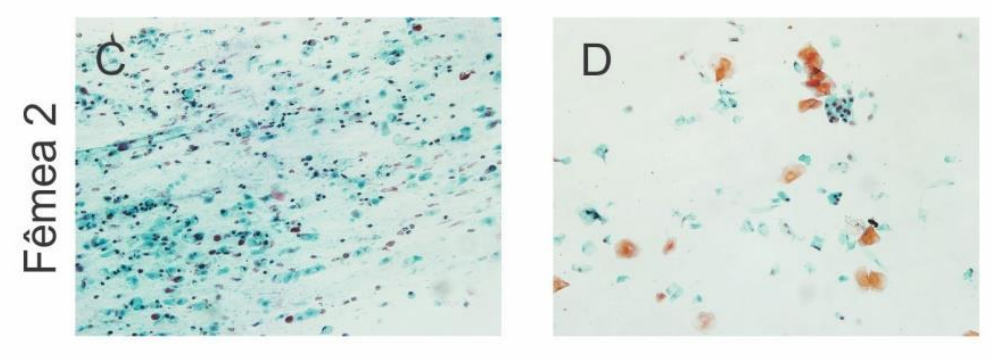

\section{Depois OVX}
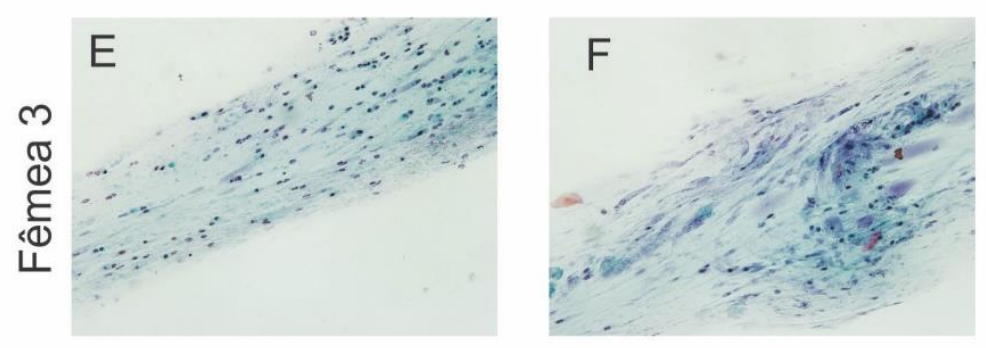

Figura 7. Confirmação da eficiência da ovarectomia. Citologia de esfregaço vaginal corados por Shorr. As amostras antes OVX foram coletadas 4 e 5 dias antes da cirurgia (A, $B, C$ e D) e as amostras depois OVX foram coletadas 7-8 dias após a ovarectomia (E e F). A) Estro, B) Metaestro, C) Diestro, D) Proestro, E) Anestro e F) Anestro.

\subsection{Reposição Hormonal}

A eficiência dos protocolos de reposição hormonal em estimular a proliferação das células estromais foi determinada pela imunodetecção das células positivas para a proteína PCNA (do inglês: Proliferative nuclear cell antigen). O protocolo estabelecido por Martin e Finn (1968) foi eficiente e estimulou intensa positividade ao marcador de proliferação celular, exclusivamente em células estromais, enquanto as células do epitélio luminal, não apresentaram imunorreação (Figura 8-A), perfil típico da resposta proliferativa estimulada pela P4. Observou-se, que a administração de uma única dose de P4 em fêmeas ovarectomizadas é capaz de bloquear, apenas parcialmente, a proliferação das células epiteliais. Estimula a 
proliferação das células endoteliais dos capilares do estroma uterino, mas, é incapaz de estimular a proliferação dos fibroblastos endometriais (Figura 8-B). Por outro lado, a injeção de uma única dose de E2 promove a proliferação apenas dos epitélios luminal e glandular (Figura 8-C).

\section{ANTI-PCNA}
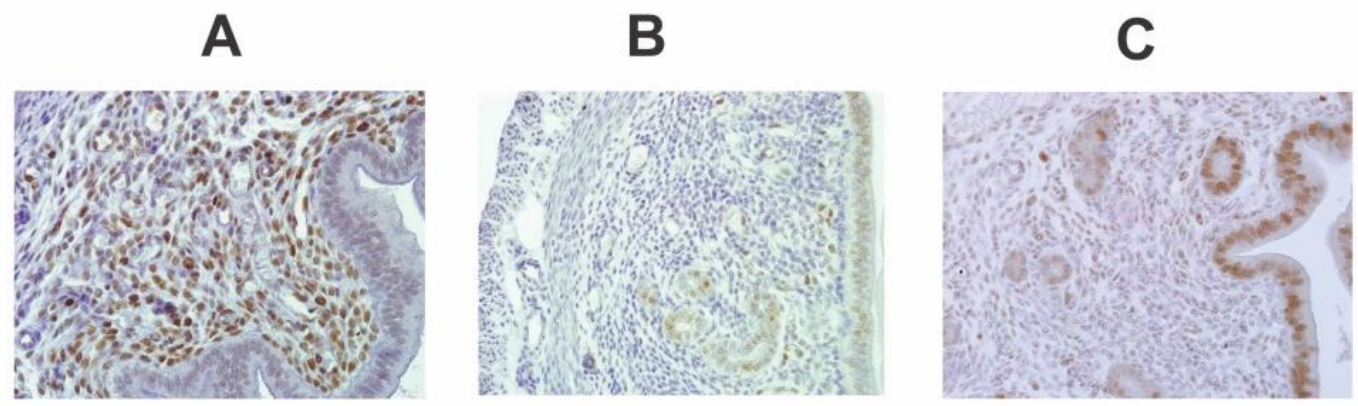

Figura 8. Protocolo de reposição hormonal. Imunodetecção para o marcador de proliferação PCNA. A) protocolo estabelecido por Martin e Finn (1974), consiste de uma dose de sensibilização de E2 $(1 \mu \mathrm{g})$ seguida 4 doses de P4 $(1 \mathrm{mg})$ com intervalos de $24 \mathrm{~h}$.

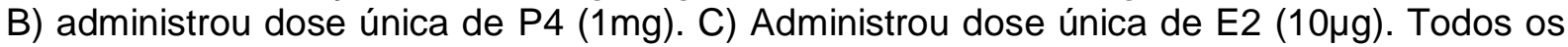
tecidos uterinos foram coletados para análise $24 \mathrm{~h}$ após a ultima dose de hormônio. Ressalta-se que o protocolo de administração utilizado no estudo foi o 8-A.

\subsection{Parâmetros Fisiopatológicos do DM}

As fêmeas diabéticas apresentaram hiperglicemia, glicosúria, diminuição do peso corporal e uterino conforme os dados apresentados na Tabela 2. De acordo com Favaro e colaboradores (2013), todos os animais com glicemia $>400 \mathrm{mg} / \mathrm{dL}$ apresentam características fisiopatológicas clássicas do diabetes do tipo 1 tais como: hiperglicemia, insulinemia, glicosúria, diminuição peso corpóreo, e aumento no consumo de água e alimento. A análise do peso corporal foi realizada utilizando apenas o peso da carcaça após a retirada do aparelho digestivo uma vez que é sabido, que os animais diabéticos apresentam uma maior ingestão de alimento, por consequência ocorre á dilatação do sistema digestório fato que mascara a perda de peso nas fêmeas diabéticas. Por essa razão o peso, apenas da carcaça, oferece maior precisão para avaliação da perda de massa corpórea de animais diabéticos. 
Tabela 2. Parametros fisiopatológicos dos grupos experimentais.

\begin{tabular}{ccc|cc}
\hline Grupo & Glicemia (mg/dL) & $\begin{array}{c}\text { Glicosúria }_{(\mathrm{mmol} / \mathrm{L})} \\
\text { OVX }\end{array}$ & $\begin{array}{c}\text { Peso }^{(\mathrm{a})} \\
(\mathrm{g})\end{array}$ & $\begin{array}{c}\text { Peso Uterino } \\
(\mathrm{mg})\end{array}$ \\
\hline OVX+DM & $183,3 \pm 7$ & $\mathrm{Nd}^{(\mathrm{c})}$ & $26,7 \pm 6$ & $40 \pm 19$ \\
OVX+P4 & $175,6 \pm 10$ & $\mathrm{Nd}^{(\mathrm{b})}$ & $26,4 \pm 5$ & $64,5 \pm 6$ \\
\hline DM+P4 & $\geq 600^{(\mathrm{b})}$ & $\geq 278$ & $21,8 \pm 5$ & $57,7 \pm 10$ \\
\hline
\end{tabular}

(a) Para evitar interferências decorrentes da maior ingestão de alimento e a dilatação do sistema digestório observado nos grupos diabéticos o peso corporal das fêmeas foi aferido após a retirada do trato digestório; (b) Limite máximo de deteç̧ão do glicosímetro AccuCheck Performa ${ }^{\circledR}$ Roche Diagnostics; (c) Nd: Não detectado.

\subsection{Peso Uterino e Histomorfometria do Endométrio}

O peso do útero das fêmeas OVX-DM foi menor $(p<0.05)$ quando comparado ao das fêmeas OVX-Controle. Embora a progesterona tenha estimulado o aumento do peso uterino, os valores foram menores nas fêmeas diabéticas $(p<0,01)$ (Tabela 2 e Figura 9).

As dimensões do estroma endometrial são semelhantes entre as fêmeas OVX controles e OVX diabéticas. O tratamento pela P4 promoveu o aumento da área do estroma endometrial no útero de ambas fêmeas, controles e diabéticas. Entretanto, a expansão do estroma endometrial foi significantemente menor em fêmeas diabéticas $(p<0,001)$ (Tabela 2 e Figura 9 ).

\section{7 Índice de Proliferação das Células Estromais}

Para identificar a contribuição de alterações na proliferação celular para a diminuição da área do estroma endometrial nas fêmeas diabéticas tratadas pela P4, analisou-se 0 índice de proliferação das células estromais por meio da Imunolocalização de PCNA. Observou-se, que a ovarectomia inibiu completamente a proliferação das células do estroma endometrial. Em contraste, as células dos 
epitélios luminal e glandular mantiveram uma alta taxa de proliferação. O protocolo de reposição hormonal utilizado foi capaz de estimular a proliferação das células do estroma endometrial e, simultaneamente, bloquear a proliferação das células dos epitélios luminal e glandular. A análise do índice proliferativo das células estromais demonstrou, que as fêmeas do grupo P4-DM apresentaram uma menor taxa proliferativa $(p<0,001)$, quando comparadas as fêmeas do grupo P4-Controle (Figura 10). 
$\Lambda$
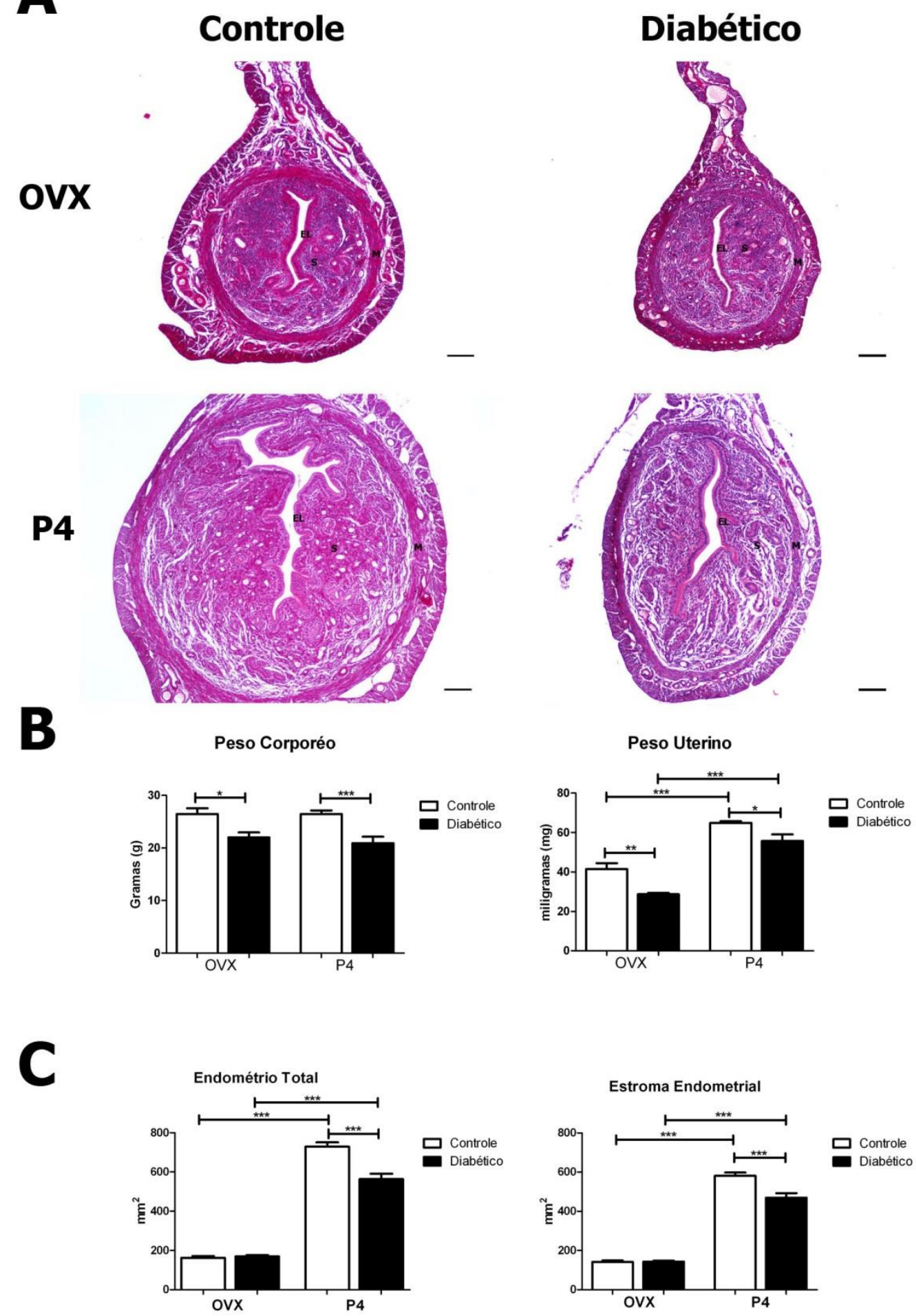

Figura 9. Alterações morfofuncionais promovidas pelo diabetes $(A)$ Cortes transversais de úteros corados por picrosirius-hematoxilina de fêmeas ovarectomizadas controles (OVXControle), ovarectomizadas diabéticas (OVX-DM), controles tratadas pela progesterona (P4Controles) e diabéticas tratadas pela progesterona (P4-DM). A ovarectomia promoveu atrofia nos compartimentos uterinos, enquanto o tratamento com $\mathrm{P} 4$ promoveu o aumento da área do endométrio (B) Representação gráfica do peso corpóreo e uterino, o diabetes provocou a diminuição do peso corporal e uterino. (C) Representação gráfica da análise histomorfométrica dos compartimentos uterinos: i) Endométrio total; ii) Estroma Endometrial. Epitélio Luminal (EL); Estroma endometrial (S); Miométrio (M). Nota-se, entretanto, que as fêmeas diabéticas tratadas (P4-DM), não obtiveram o mesmo aumento de área do 
endométrio, que as fêmeas controles. * $p<0,05 ;{ }^{* *} p<0,01 ;{ }^{* *} p<0,001$. Barra de aumento $=$ $50 \mu \mathrm{m}$.
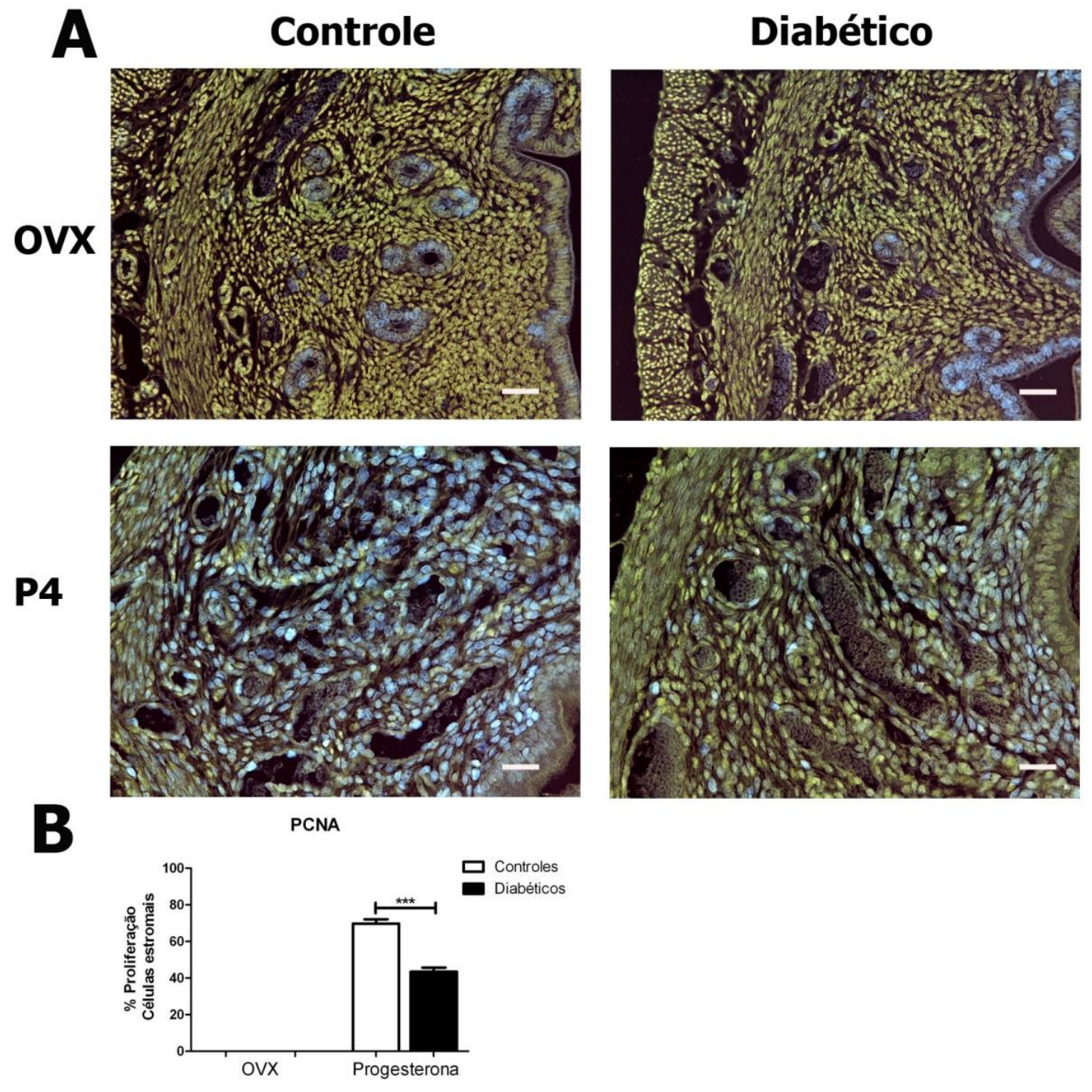

Figura 10. Impacto do diabetes na proliferação das células estromais uterina. A) Imunolocalizaçãode PCNA no útero das fêmeas ovarectomizadas controles (OVX-Controle); ovarectomizadas diabéticas (OVX-DM); controles tratadas pela progesterona (P4-Controles); diabéticas tratadas pela progesterona (P4-DM). Nas fêmeas OVX-controles e OVXdiabéticas, células positivas ao PCNA estavam restritas aos epitélios luminal e glandular. Não foram observadas células positivas ao PCNA no estroma endometrial. Contrariamente, nas fêmeas tratadas pela progesterona foram observadas células positivas ao PCNA no estroma mas, não nos epitélios. As cores foram invertidas para destacar a marcação. (B) Representação gráfica do índice proliferativo das células do estroma endometrial mostrando que o diabetes inibiu a resposta proliferativa das células do estroma endometrial em fêmeas tratadas pela progesterona. ${ }^{* *} p<0,001$. A barra representa $20 \mu \mathrm{m}$. 


\subsection{Níveis Proteicos dos Receptores de Progesterona}

A avaliação dos níveis protéicos dos PRs por Western blot foi realizada utilizando-se um anticorpo policlonal capaz de reconhecer ambas isoformas, PR-A e PR-B. Observou-se: (a) a presença de quatro bandas intermediárias entre as bandas correspondentes ao PR-A ( $\approx 83 \mathrm{kDa})$ e PR-B ( $\approx 116 \mathrm{kDa})$. (b) aumento dos níveis do PR-A no compartimento citoplasmático das fêmeas OVX-DM e tratadas pela P4-DM, em relação aos seus respectivos controles; (c) ausência de alterações nos níveis do PR-A nuclear entre os grupos experimentais (d) semelhança entre os níveis do PR-B nucleares e citoplasmáticos entre as fêmeas controle e diabéticas (e) diminuição da relação entre o PR-B e o PR-A nos compartimentos nuclear e citoplasmático das fêmeas P4-DM (Figura 11. B).

Adicionalmente, a avaliação do conjunto das bandas intermediárias demonstrou que houve aumento na fração citoplasmática em amostras de fêmeas OVX-DM quando comparada às de fêmeas OVX-Controles. Em contraste, detectouse diminuição na fração citoplasmática dos subprodutos dos receptores nas amostras de fêmeas diabéticas tratadas pela P4 quando comparadas ao controle. $\mathrm{Na}$ fração nuclear, entretanto, houve um aumento nos subprodutos dos receptores das fêmeas OVX-DM e tratadas pela $\mathrm{P} 4$, em relação aos seus respectivos controles (Figura 11. C).

Em adição, o tratamento pela P4 diminuiu os níveis citoplasmáticos do PR-A e do PR-B nas fêmeas controles e diabéticas. Não houve alteração nos níveis proteicos desses receptores no compartimento nuclear. Por outro lado, o tratamento pela P4 aumentou as formas intermediárias desses receptores na fração citoplasmática das fêmeas controles e diminuiu nas fêmeas diabéticas. Na fração nuclear, o tratamento pela P4 aumentou os níveis desses receptores em ambas, fêmeas controle e diabéticas.

\subsection{Distribuição dos Receptores de Progesterona nos Tecidos Uterinos}

O anticorpo utilizado nos experimentos de Western blot, capaz de reconhecer as isoformas PR-A e PR-B, foi também empregado para a avaliação da distribuição dos PR nos compartimentos endometriais por imunofluorescência. Observamos, em todos os grupos analisados, a presença desses receptores nas células endometriais 
estromais e também dos epitélios luminal e glandular. A co-localização da imunorreação com a marcação pelo DAPI, um corante nuclear, demonstrou a existência de imunorreação nos compartimentos citoplasmático e, principalmente, nucleares das células endometriais. Nas fêmeas OVX-Controle e OVX-DM, o epitélio luminal apresentou-se intensamente marcado. Em adição, a imunorreação presente no epitélio luminal das fêmeas OVX-DM foi mais intensa do que nas fêmeas OVXcontrole. Nas fêmeas submetidas à reposição pela $\mathrm{P} 4$, houve aumento na imunoreatividade nas células do estroma endometrial paralelamente com diminuição nas células epiteliais. No entanto, não foram observadas alterações entre os grupos P4Controle e P4-DM (Figura 12). 


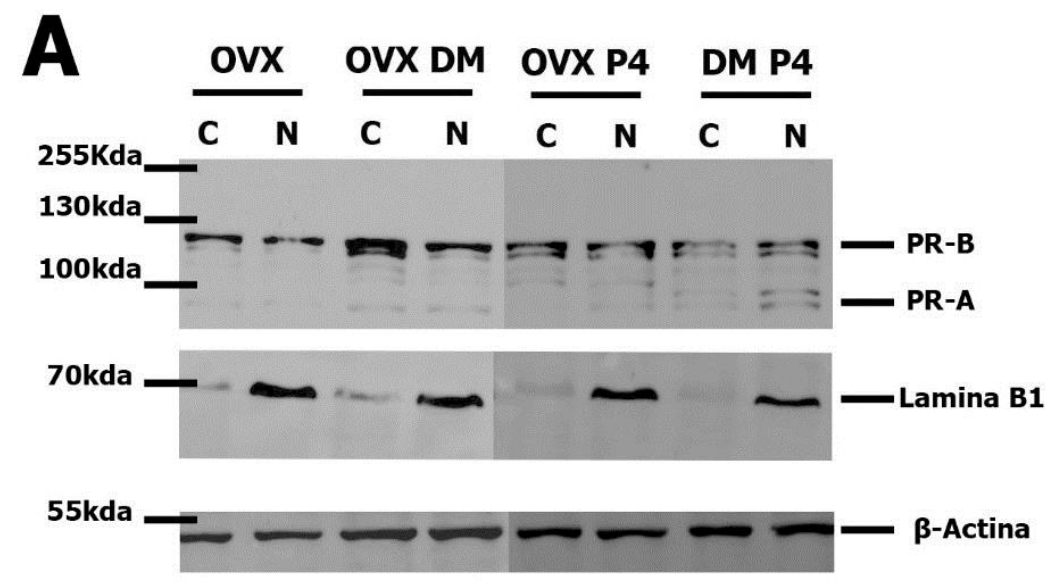

B
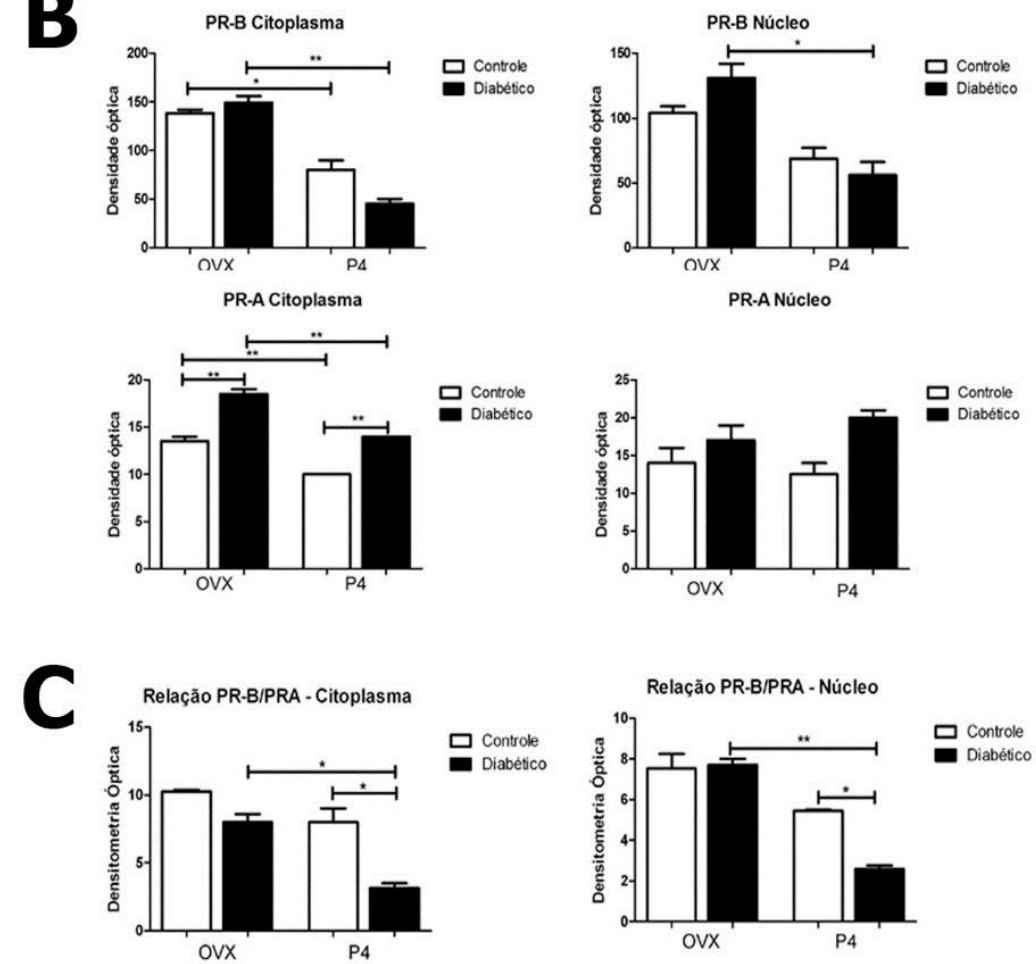

Figura 11. Detecção da expressão protéica do receptor de progesterona. (a) Western Blot para detectar PR-B $(\approx 116 \mathrm{kDa})$, PR-A $(\approx 83 \mathrm{KDa})$ e Lamina B1 $(\approx 65 \mathrm{kDa})$ proteína nuclear para controle de separação dos lisado protéicos: citoplasmáticos $(C)$ nuclear $(N)$ fêmeas controles e diabéticas (DM), ovarectomizadas (OVX) e submetidas reposição hormonal com progesterona (P4). A $\beta$-actina $(\approx 42 \mathrm{kDa})$ foi utilizada como proteína normalizadora. (B) Quantificação protéica realizada por densitometria óptica e relação da densidade entre as isoformas (PR-B: PR-A). O diabetes promoveu alterações na expressão proteíca do PR-A. A relação entre PRA e PRB mostrou aumento do PR-A nas fêmeas diabéticas tratados com P4 comparada com Controle P4. (c) Quantificação dos subprodutos do PR, nota-se, tanto o diabetes como o tratamento com a $\mathrm{P} 4$, modificam o perfil de expressão destes subprodutos protéicos. ${ }^{*} p<0,05 ;{ }^{* *} p<0,01 ;{ }^{* *} p<0,001$. 


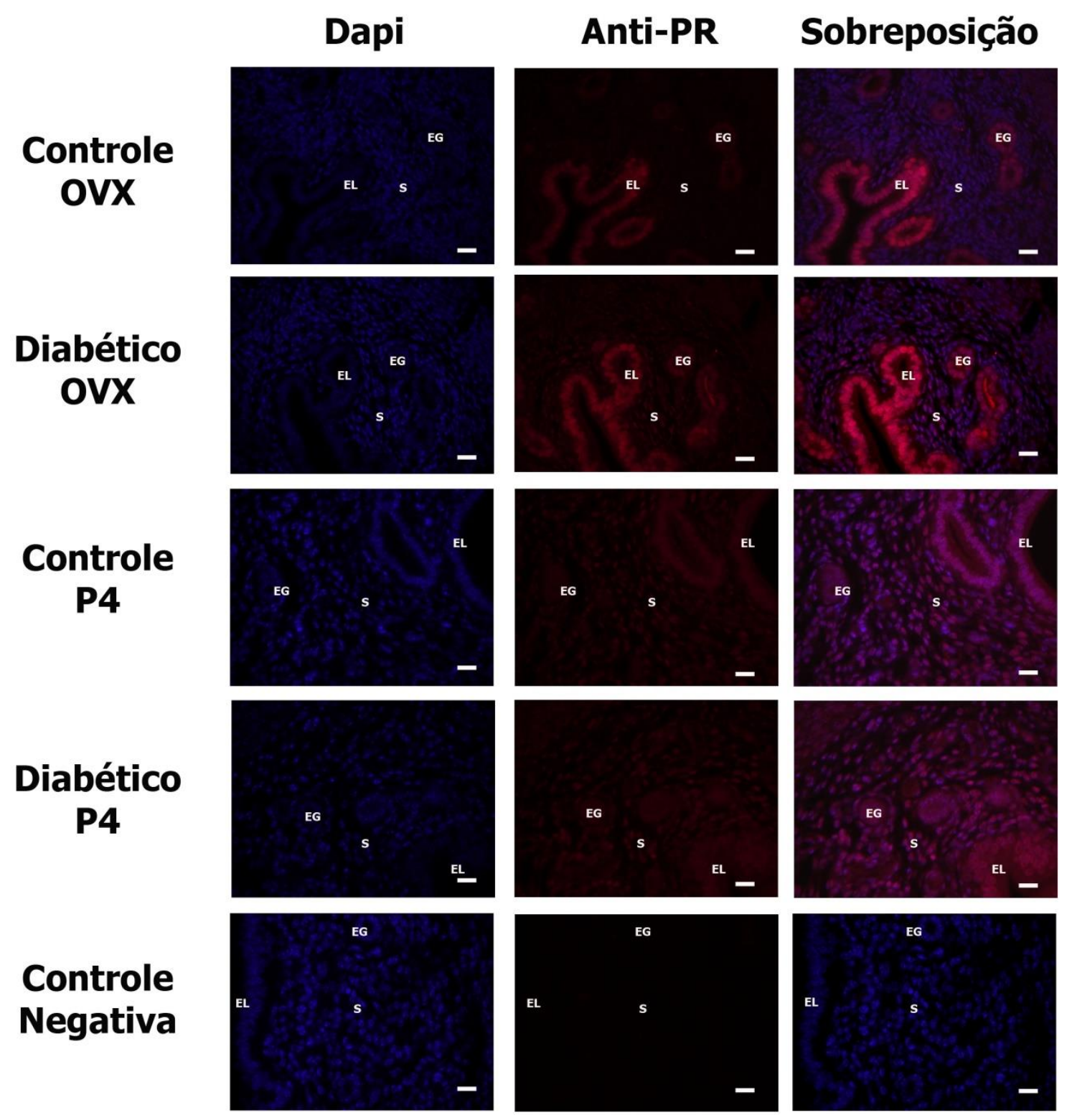

Figura 12. Análise por imunofluorescência da distribuição dos receptores de progesterona (PR-A+PR-B) no útero de fêmeas ovarectomizadas controles (OVXControle), ovarectomizadas diabéticas (OVX-DM) e controles tratadas pela progesterona (P4-Controles) e diabéticas tratadas pela progesterona (P4-DM). Observa-se imunorreação nas células do estroma endometrial e dos epitélios luminal e glandular em todos os grupos experimentais. O epitélio luminal de fêmeas ovarectomizadas apresentou uma intensa marcação que foi mais intensa, nas amostras de fêmeas diabéticas. Nas amostras de fêmeas tratadas pela progesterona nota-se uma diminuição da imunorreação no epitélio luminal e aumento no estroma endometrial. Não foram observadas diferenças significativas entre as fêmeas P4-Controles e P4-DM. Epitélio Luminal (EL); Epitélio Glandular (EG); Estroma Endometrial (S). A barra representa $20 \mu \mathrm{m}$. 


\subsection{Análises da Expressão Gênica PR-B, PRA+B, das Ciclinas D1, E1 p27, FGF-2 e Hoxa-10}

As análises da expressão génicas foram realizadas em alvos que modulam e/ou sofrem modulação da P4, tais como os PRs, proteínas que controlam o ciclo celular (ciclina D1, ciclina E1 e p27) e os fatores transcrição e crescimento (Hoxa-10 e FGF-2) que são envolvidos na proliferação das células do estroma uterino.

Quando analisou-se os níveis da expressão dos PRs não foram observadas alterações entre os grupos experimentais (Figura 13 - A). Entre as proteínas que controlam o ciclo celular, a expressão do RNAm da p27 estava aumentada nas fêmeas OVX-DM em relação às fêmeas OVX-Controle $(p<0,05)$. O tratamento pela P4 equalizou a expressão de p27 entre as fêmeas controle e diabéticas. Não foram detectadas alterações nos níveis do RNAm das ciclinas D1 e E1 entre os grupos experimentais (Figura 13 - B). As análises do Hoxa-10 - fator de transcrição, que modula a proliferação celular das células estromais - mostrou que ele é expresso em níveis basais em ambos os grupos OVX e OVX-DM. O tratamento com a P4 estimula a expressão do RNAm do Hoxa-10; entretanto, sua expressão no grupo DM-P4 é menor quando comparada com o grupo OVX-P4 $(p<0,001)$. Não foram detectadas alterações na expressão do FGF-2 em nenhum dos grupos analisados (Figura 13 C). 


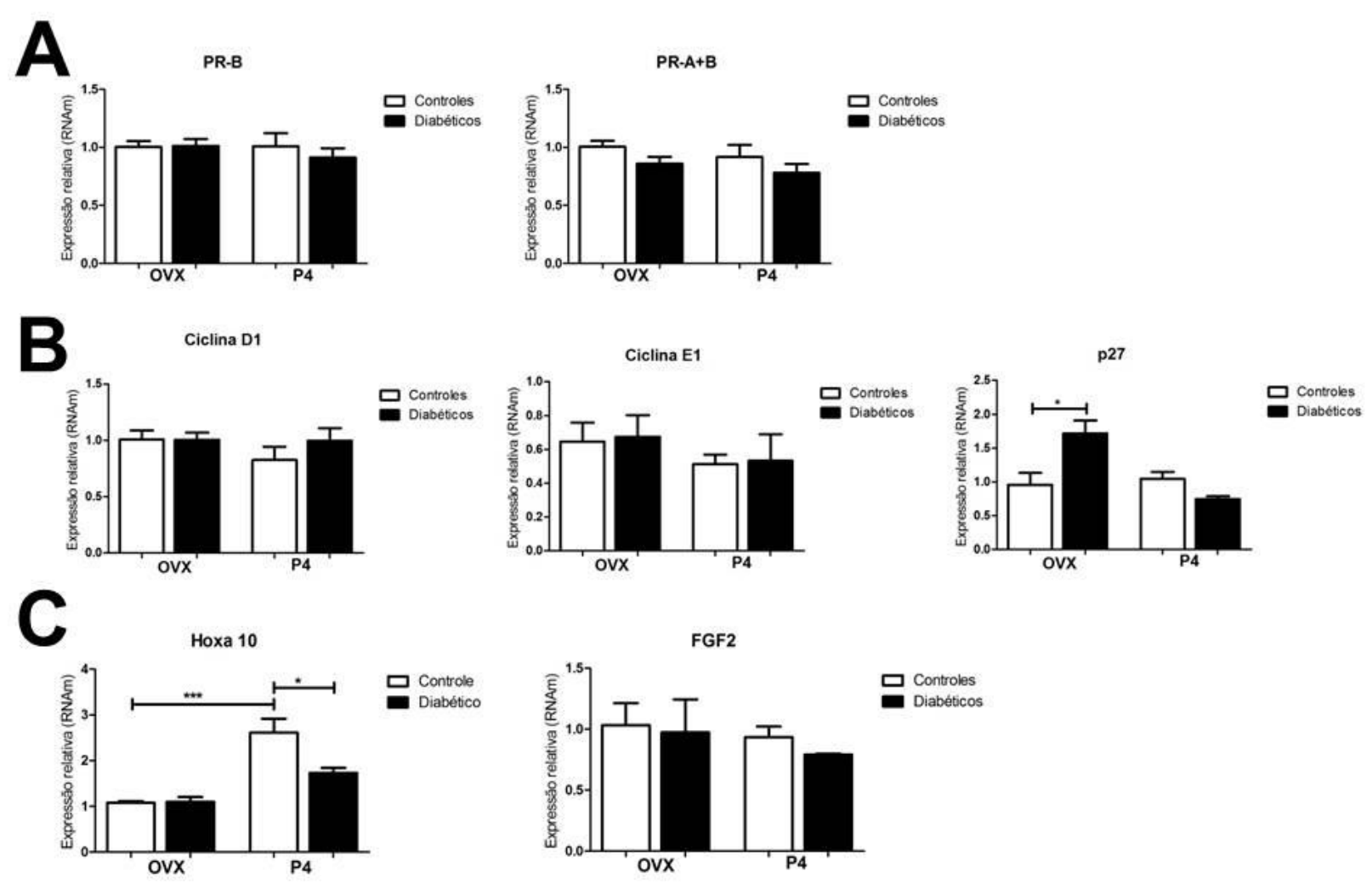

Figura 13. Genes que controlam a maquinaria do ciclo celular das células do estroma uterino. Quantificação relativa da expressão gênica por qPCR: (A) Receptores de Progesterona; (B) Genes que controlam o ciclo celular; (C) Fatores de crescimento e transcrição. Em fêmeas controles e diabéticas (DM), ovarectomizadas (OVX) e submetidas reposição hormonal com progesterona (P4). A expressão do RNAm do gene p27 está aumentada significantemente $(p<0,05)$ em fêmeas $O V X+D M$ em relação aos controles OVX. Do mesmo modo, o tratamento com P4 aumenta significantemente a expressão do Hoxa-10 nos animais controles $(p<0,001)$. No grupo $D M+P 4$, entretanto, o aumento não é estatisticamente significante. ${ }^{*} p<0,05 ;{ }^{* *} p<0,01 ;{ }^{* * *} p<0,001$.

\subsection{Níveis Séricos de P4 e E2}

Com intuito de comparar os níveis séricos dos hormônios P4 e E2 entre os grupos normoglicêmicos e diabéticos, realizamos dosagem séricos desses hormônios em amostras de sangue coletadas 24 horas após a ultima injeção de E2 e P4.

A dosagem demonstrou, entretanto, que não houve alteração nos níveis séricos desses hormônios em ambos, animais OVX e OVX+DM. Além disso, não foi observado aumento da P4, embora esse hormônio tenha sido administrado por via 
exógena. Adicionalmente, o protocolo de reposição hormonal promoveu no grupo $\mathrm{DM}+\mathrm{P} 4$, a diminuição dos níveis de $\mathrm{P} 4(\mathrm{p}<0,001)$ e $\mathrm{E} 2(\mathrm{p}<0,05)$.
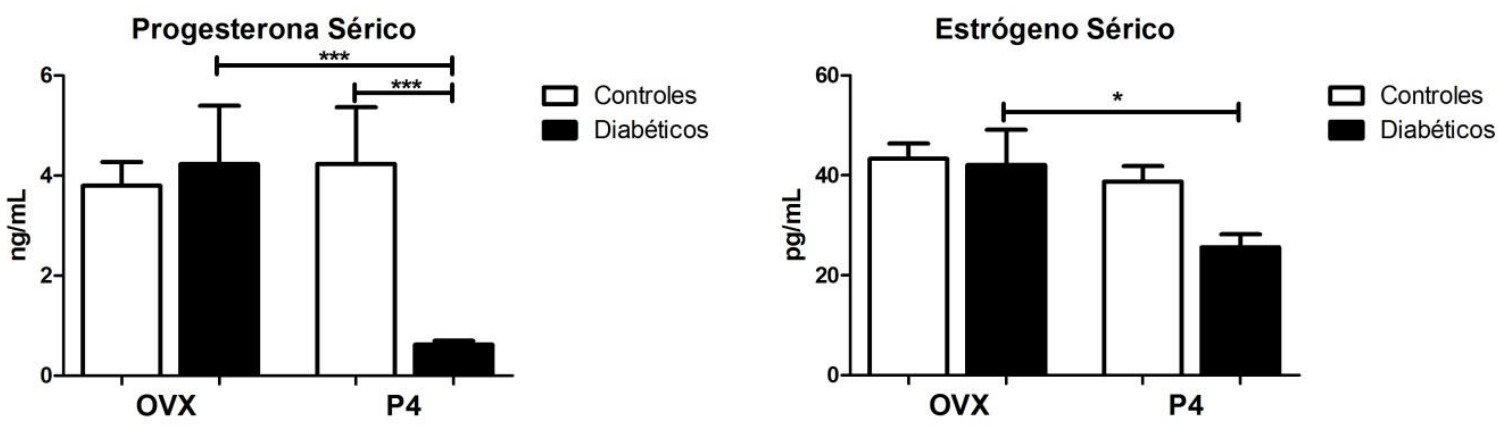

Figura 14. Níveis séricos dos hormônios esteroides ovarianos. Analises realizadas no soro das fêmeas ovarectomizadas controles (OVX-Controle), ovarectomizadas diabéticas (OVX-DM) e controles tratadas pela progesterona (P4-Controles) e diabéticas tratadas pela progesterona (P4-DM). Observamos que o tratamento com a P4 promoveu redução dos níveis hormonais séricos nas fêmeas P4-DM. * $p<0,05 ;{ }^{* *} p<0,01 ;{ }^{* * *} p<0,001$. 
5 DISCUSSÃo 
Sabe-se que os efeitos do diabetes sobre o sistema reprodutivo feminino são complexos e multifatoriais e existem evidências de que esta doença afeta as estruturas neuroendócrinas, que controlam o ciclo reprodutivo e, em consequência a fisiologia dos ovários e do útero. Consequentemente, mulheres diabéticas apresentam distúrbios na fertilidade e complicações gestacionais. Modelos animais, entre esses, aquele desenvolvido em camundongos por nosso grupo (FAVARO et al., 2013) mostraram-se capazes de identificar várias alterações morfofisiológicas no sistema reprodutor. Tornam-se, portanto, um importante instrumento para ampliar nosso conhecimento sobre essa doença.

De fato, os resultados do presente estudo expandem o conhecimento sobre 0 impacto do diabetes nos processos reprodutivos e apresentam novas evidências morfofisiológicas que enriquecem o conhecimento nessa área. São elas: (i) a sinalização da P4 no ambiente uterino é comprometida pelo diabetes (ii) a alteração na sinalização da P4 altera sua ação sobre a proliferação celular do estroma endometrial, (iii) essas alterações na sinalização da P4 são associadas com alterações nos níveis de seus receptores.

Importantemente, no presente estudo demostrou-se, que os animais DM1 resistem ao procedimento cirúrgico e a protocolo de reposição hormonal, garantindo, portanto, a sua utilização como modelo experimental viável.

A abordagem experimental de redução dos níveis hormonais por meio da OVX é uma das principais abordagens para estudos in vivo dos mecanismos regulatórios dos hormônios esteroides ovarianos. No entanto, a literatura é carente de dados sobre análises dos níveis hormonais séricos em experimentos com protocolos de OVX e reposição hormonal. Podemos atribuir a inexistência destes dados às dificuldades inerentes da coleta de sangue em roedores. Acresce-se o fato de que os primeiros métodos desenvolvidos para analise de hormônios esteroides séricos possuírem baixa sensibilidade. Adicionalmente, destaca-se também a difícil compressão do complexo metabolismo da síntese e depuração (clearance) dos hormônios esteroides, o que pode gerar dados conflitantes. De fato, as análises dos níveis séricos dos hormônios P4 e E2 realizadas no presente estudo não foram capazes de demonstrar o aumento promovido pela reposição contínua da P4 (Figura 14). Além disso, os níveis dos hormônios de todos os grupos estão abaixo dos níveis fisiológicos quando comparados com resultados já existentes na literatura (WOOD et al., 2007). Entretanto, verificamos que o tratamento com $\mathrm{P} 4$ promoveu, nos grupos 
diabéticos, uma redução dos níveis séricos de P4 e E2. Estudos in vitro demonstraram, que a ausência da insulina está associada a uma maior depuração da P4 (SMITH et al., 2006). Além disso, estudos com modelos de DM1 induzida apresentam aumento na excreção via urinária, da P4 após dois dias da indução do diabetes (KUZNETSOVA et al., 2013; SELYATITSKAYA et al., 2012). Diante desses dados acreditamos, que os grupos de animais diabéticos, mas, que não foram submetidos à reposição hormonal, estabilize a depuração de P4 em consequência do longo período sem flutuações dos hormônios circulantes, decorrente da OVX. No entanto, nossos resultados nos leva a propor, que a administração continuada dos hormônios promove uma superativação do catabolismo da P4 e depuração dos hormônios e, por consequência, uma exacerbação da excreção dos hormônios por via urinária.

Sabe-se que a P4 necessita de seu PR para exercer suas funções biológicas. Adicionalmente, já está demonstrado que as isoformas do PR, PR-A e PR-B, possuem pouca equivalência funcional fato que leva a efeitos distintos de suas sinalizações. Enquanto o PR-B tem uma maior atividade transcricional, o PR-A atua, em parte, como repressor da expressão de genes ativados por PR-B, ERa e receptores de andrógenos (GIANGRANDE; POLLIO; MCDONNELL, 1997; HOVLAND et al., 1998). Neste contexto, é importante enfatizar, que os níveis do PR$A$ e do PR-B podem determinar a resposta de células à P4. De fato, já foi demonstrado, que a relação entre estes receptores está comprometida em doenças como câncer e endometriose (CORK; LENNARD; TYSON-CAPPER, 2012; FANG et al., 2004; SASAKI et al., 2001).

Os nossos dados demonstraram, que o diabetes promove um aumento significativo do PR-A na fração citoplasmática das fêmeas tanto ovarectomizadas como aquelas tratadas pela P4. Além disso, nossos resultados mostraram, que as fêmeas diabéticas tratadas pela $\mathrm{P} 4$ apresentaram um desbalanço na relação entre o PR-B/PR-A, tanto no compartimento citoplasmático como no nuclear. Estes resultados indicam, que ambas as sinalizações genômica e não-genômica da P4, podem ter sido afetadas pelo diabetes.

Além das tradicionais isoformas do PR, diversas outras formas truncadas por splicing alternativo, têm sido demonstradas (CORK; LENNARD; TYSON-CAPPER, 2008). No splicing alternativo, diferentes conjuntos de exons são adicionados ou removidos e/ou também, regiões intrônicas são mantidas durante o processamento 
do RNAm (FU; ARES, 2014). De fato, nossas avaliações por Western blot identificaram bandas intermediárias entre aquelas correspondentes às isoformas do PR-A e PR-B as quais, provavelmente, representam isoformas truncadas que podem ter sofrido modificações pós-traducionais. Nossos experimentos mostraram ainda, que o diabetes altera a expressão protéica destas isoformas, aqui referidas como intermediárias. As alterações foram detectadas em ambos, núcleo e citoplasma de fêmeas ovarectomizadas submetidas ou não à reposição pela P4. Graças ao papel central dos PR na proliferação celular do endométrio, o seu desbalanço pode estar relacionado à menor taxa proliferativa das células do estroma uterino.

O protocolo de reposição hormonal adotado no presente estudo foi capaz de promover uma intensa proliferação dos fibroblastos endometriais. Dados anteriores (MARTIN; FINN, 1968; RIDER et al., 2006) descrevem, que os fibroblastos endometriais iniciam sua proliferação a partir de $6 \mathrm{~h}$ após a última dose de P4, atingindo valores máximos de células em atividade mitótica por volta de $24 \mathrm{~h}$ diminuindo, após esse período, a resposta proliferativa. De fato, nosso estudo mostrou, que ocorreu o aumento da área do estroma endometrial nas fêmeas tratadas pela P4 a qual, entretanto, foi menor nas fêmeas diabéticas. Por outro lado, não foram observadas diferenças nos valores obtidos pelo cálculo da relação entre o peso uterino e o peso corporal dos animais, realizado para relativizar a perda de peso corporal das fêmeas diabéticas ao peso uterino. Estes resultados demonstram a importância da avaliação do peso uterino associada à histomorfometria dos seus compartimentos, para uma avaliação precisa e melhor compreensão dos efeitos de determinado tratamento experimental sobre este órgão e, em particular, sobre o endométrio. A avalição do índice de proliferação das células do estroma endometrial mostrou, que a redução na capacidade proliferativa das fêmeas diabéticas, quando estimuladas pela P4, está associada à menor dimensão do estroma endometrial.

De fato, tem sido demonstrado que os efeitos do diabetes sobre a proliferação celular variam de acordo com o tipo celular. Existem evidências de que esta doença aumenta a proliferação de células musculares lisas vasculares (NATARAJAN et al., 1999), células epiteliais da bexiga (EIKA et al., 1993) e células trofoblásticas (ZORN et al., 2011) enquanto, reduz a proliferação de fibroblastos epidermais (SIBBITT et al., 1989) e células renais (LIU et al., 2012). Resultados anteriores do nosso grupo demonstraram que o diabetes diminui significantemente a proliferação celular das células musculares do miométrio durante o início da gestação promovendo uma 
menor espessura das camadas musculares (FAVARO et al., 2010). Em adição, resultados de outro estudo do nosso grupo (FAVARO; DALBOSCO; ZORN, resultados não publicados) mostraram que o diabetes aumenta a proliferação celular do epitélio uterino, em fêmeas ovarectomizadas sem reposição hormonal, e compromete a ação do E2 sobre a sua proliferação. A diminuição da proliferação das células epiteliais uterinas em ratas diabéticas ovarectomizadas e tratadas por estrógeno foi também observada por Kirkland e colaboradores (KIRKLAND; BARRETT; STANCEL, 1981).

Em conjunto, estes dados indicam fortemente, que o diabetes compromete a ação proliferativa dos hormônios E2 e P4 no ambiente uterino. É indiscutível que a proliferação e diferenciação das células do estroma uterino são processos cruciais para a fisiologia uterina. Dessa forma, alterações nesse processo podem contribuir para o desenvolvimento de complicações reprodutivas, resultando em dificuldade na implantação embrionária e abortos (JENSEN et al., 2004; VARGAS; REPKE; URAL, 2010).

A super-expressão do PR-A no útero de camundongos, entre outros efeitos, promoveu o aumento da proliferação das células epiteliais (FLEISCH et al., 2009). Portanto, é lícito propor, que o aumento da proliferação do epitélio uterino nas fêmeas diabéticas ovarectomizadas (FAVARO; DALBOSCO; ZORN, resultados não publicados) pode estar relacionado com a elevação dos níveis proteicos do PR-A citoplasmático. De fato, os dados obtidos pelas análises de imunofluorescência mostram maior quantidade destes receptores nas células epiteliais das fêmeas diabéticas ovarectomizadas.

Os principais pontos de regulação do ciclo celular por hormônios e fatores de crescimento são as transições entre G0-G1-S. A superação do estado de quiescência depende da expressão de Ciclinas do tipo $D$ que, por sua vez interagem com as Cdks 4/6 acionando a atividade fosforilativa desta última. Em adição, a superação do ponto de restrição depende da presença das Ciclinas do tipo E, interagindo com a Cdk 2 (FAVARO, 2013). No ambiente uterino estes processos são regulados por hormônios esteroides (MUSGROVE; SUTHERLAND, 1994). Para proliferarem, as células do estroma uterino dependem da presença dos receptores de E2 e P4, que além de promoverem a expressão de ciclinas, diminuem os níveis dos inibidores do ciclo celular como p21 e p27 (SHIOZAWA et al., 1998). 
A análise da expressão gênica da ciclina D1 e E1 não revelaram alterações entre os grupos controles e diabéticos. Entretanto, atribuímos a não observação do aumento da expressão das ciclina D1 e E1 nas fêmeas tratadas pela P4, quando comparadas as fêmeas ovarectomizadas, ao momento em que as amostras uterinas foram coletadas. Verificamos, que aproximadamente $70 \%$ dos fibroblastos endometriais estavam positivos ao PCNA, identificador de células nas fases $\mathrm{S}$, G2 e $M$. Esse fato indica, que grande parte das células havia ultrapassado a fase G1/S, na qual a ciclina D1 e E1 é produzida. Nossos resultados indicam também, que a expressão gênica da ciclina D1 e E1 não são alteradas pelo diabetes. Não excluem, porém, que ocorram alterações nos seus níveis protéicos. Estudos adicionais são necessários para verificar a contribuição de outros membros da família de ciclinas para as alterações promovidas pelo diabetes na proliferação dos fibroblastos endometriais.

Os níveis do RNAm da p27 estão aumentados nas fêmeas diabéticas ovarectomizadas. Sugerimos, que a alta expressão de p27 possa atuar como um fator dificultador da atividade proliferativa no útero das fêmeas diabéticas, impedindo a resolução da quiescência (G0) e entrada das células na fase $\mathrm{G} 1$ do ciclo celular (LABAER et al., 1997). Entretanto, no momento em que a proliferação celular foi avaliada nas fêmeas tratadas pela P4, os níveis de p27 foram semelhantes entre os grupos controle e diabético. Estudos realizados em rins de camundongos diabéticos demonstraram, que a exposição à alta concentração de glicose promoveu um aumento da expressão gênica e síntese proteica da p27, relacionando a nefropatia diabética com a diminuição da proliferação das células mesangiais renal (LIU et al., 2012; WOLF et al., 2001). Além disso, fatores de transcrição e fatores de crescimento são necessários para que as células estromais proliferem de maneira adequada. O Hoxa-10 é um fator de transcrição membro da família de genes homeobox, os quais tem papel fundamental no desenvolvimento embrionário (SATOKATA; BENSON; MAAS, 1995). No entanto, em fêmeas adultas, a expressão desse fator é aumentada, quando as células estromais uterinas iniciam sua atividade proliferativa na gestação. Estudos com animais nocautes para o Hoxa-10 apresentaram diminuição da capacidade de proliferação das células estromais uterinas o que, por sua vez, prejudica a implantação embrionária (LIM et al., 1999). Nossos dados demonstram, que o protocolo de reposição estimula a expressão do fator de transcrição Hoxa-10. Em contraste, diferentemente dos animais controle, 
quando estimulados pela P4 os animais DM1 mostram níveis diminuídos do RNAm da Hoxa-10. Sabendo que a expressão do Hoxa-10 é principalmente regulado pela P4 (GODBOLE; MODI; PURI, 2007; LIM et al., 1999), propomos, que o conjunto de alteração nos PRs levam à diminuição da expressão do RNAm do Hoxa-10, resultando em diminuição da capacidade proliferativa das células estromais uterinas das fêmeas DM1.

Em conclusão, os resultados obtidos neste estudo e aqui descritos, contribuem para uma melhor compreensão do impacto do diabetes sobre ação da P4 no ambiente uterino, em particular, sobre a proliferação celular, eventos que podem estar associados aos distúrbios reprodutivos provocados pelo diabetes. Ressaltamos, que mais estudos são necessários para identificar o conjunto de mecanismos biológicos pelos quais o diabetes interfere na sinalização dos hormônios esteroides, o que poderá possibilitar futuras intervenções para o tratamento de alterações reprodutivas associadas à esta doença. 
6 CONCLUSÕES 
Os resultados obtidos neste presente estudo nos permitiram demonstrar que:

1. Os animais submetidos à indução farmacológica de Diabetes Mellitus do tipo 1 (DM1), por meio de Aloxana, resistem ao protocolo de ovarectomia e reposição hormonal tornando-se, portanto, um modelo viável;

2. O DM1 promove alterações biologicamente significativas na estrutura do endométrio;

3. O comprometimento na estrutura do endométrio, promovido pelo DM1, está associado à redução da capacidade proliferativa dos fibroblastos uterinos;

4. A redução na resposta proliferativa do endométrio à progesterona, observada nos animais diabéticos, está diretamente correlacionada com alterações nos níveis proteicos dos receptores de progesterona;

5. O DM1 reduz a resposta proliferativa do endométrio por meio do aumento na expressão do RNAm de proteínas inibidoras do ciclo celular, como a p27.

6. Em adição, o conjunto de danos provocados pelo DM1 no ambiente uterino prejudica a expressão de fatores, que controlam a progressão do ciclo celular dos fibroblastos uterino, como o fator de transcrição Hoxa- 10. 
REFERÊNCIAS 


\section{REFERÊNCIAS}

ABRAHAMSOHN, P. A.; ZORN, T. M. Implantation and decidualization in rodents. J. Exp. Zool., v. 266, n. 6, p. 603-628, 1993.

ALBERTS, B.; LEWIS, J.; MARTIN, R. K.; ROBERTS, K. W. Molecular biology of the cell. $5^{\text {th }}$ ed. New York: Garland Science, 2007.

ALLEN, W. E. An improved closing bottle for subsurface sampling of fluids. Science, v. 65, n. 1673, p. $66-67,1927$.

AMERICAN DIABETES ASSOCIATION. Diagnosis and classification of diabetes mellitus. Diabetes Care, v. 34, p. S62-S69, 2011. Suppl.

AUPPERLEE, M. D.; HASLAM, S. Z. Differential hormonal regulation and function of progesterone receptor isoforms in normal adult mouse mammary gland. Endocrinology, v. 148, n. 5, p. 2290-2300, 2007.

BAKER, J.; HARDY, M. P.; ZHOU, J.; BONDY, C.; LUPU, F.; BELLVE, A. R.; EFSTRATIADIS, A. Effects of an Igf1 gene null mutation on mouse reproduction. Mol. Endocrinol., v. 10, n. 7, p. 903-918, 1996.

BASERGA, R.; WIEBEL, F. The cell cycle of mammalian cells. Int. Rev. Exp. Pathol., v. 7, p. 1-30, 1969.

BOONYARATANAKORNKIT, V.; EDWARDS, D. P. Receptor mechanisms mediating non-genomic actions of sex steroids. Semin. Reprod. Med., v. 25, n. 3, p. 139-153, 2007.

CARSON, D. D.; BAGCHI, I.; DEY, S. K.; ENDERS, A. C.; FAZLEABAS, A. T.; LESSEY, B. A.; YOSHINAGA, K. Embryo implantation. Dev. Biol., v. 223, n. 2, p. 217-237, 2000.

CASSON, I. F.; CLARKE, C. A.; HOWARD, C. V.; MCKENDRICK, O.; PENNYCOOK, S.; PHAROAH, P. O.; PLATT, M. J.; STANISSTREET, M.; VAN VELSZEN, D.; WALKINSHAW, S. Outcomes of pregnancy in insulin dependent diabetic women: results of a five year population cohort study. Bmj., v. 315, n. 7103, p. 275-278, 1997.

CHABROLLE, C.; JEANPIERRE, E.; TOSCA, L.; RAME, C.; DUPONT, J. Effects of high levels of glucose on the steroidogenesis and the expression of adiponectin receptors in rat ovarian cells. Reprod. Biol. Endocrinol., v. 6, p. 11, 2008.

CHAPPELL, P. E.; LYDON, J. P.; CONNEELY, O. M.; O'MALLEY, B. W.; LEVINE, J. $E$. Endocrine defects in mice carrying a null mutation for the progesterone receptor gene. Endocrinology, v. 138, n. 10, p. 4147-4152, 1997.

De acordo com:

ASSOCIAÇÃO BRASILEIRA DE NORMAS TÉCNICAS. NBR 6023: informação e documentação:

referências: elaboração. Rio de Janeiro, 2002. 
CHENG, J. G.; CHEN, J. R.; HERNANDEZ, L.; ALVORD, W. G.; STEWART, C. L. Dual control of LIF expression and LIF receptor function regulate Stat3 activation at the onset of uterine receptivity and embryo implantation. Proc. Natl. Acad. Sci., v. 98 , n. 15, p. 8680-8685, 2001.

CHWALISZ, K. The use of progesterone antagonists for cervical ripening and as an adjunct to labour and delivery. Hum. Reprod., v. 9 Suppl 1, p. 131-161, 1994.

COATS, S.; FLANAGAN, W. M.; NOURSE, J.; ROBERTS, J. M. Requirement of p27Kip1 for restriction point control of the fibroblast cell cycle. Science, v. 272, n. 5263, p. 877-880, 1996.

CONNEELY, O. M.; KETTELBERGER, D. M.; TSAI, M. J.; SCHRADER, W. T.; O'MALLEY, B. W. The chicken progesterone receptor $A$ and $B$ isoforms are products of an alternate translation initiation event. J. Biol. Chem., v. 264, n. 24, p. 1406214064, 1989.

CORK, D. M.; LENNARD, T. W.; TYSON-CAPPER, A. J. Alternative splicing and the progesterone receptor in breast cancer. Breast. Cancer Res., v. 10, n. 3, p. 207, 2008.

CORK, D. M.; LENNARD, T. W.; TYSON-CAPPER, A. J. Progesterone receptor (PR) variants exist in breast cancer cells characterised as PR negative. Tumour Biol., v. 33, n. 6, p. 2329-40, 2012.

COUSE, J. F.; KORACH K. S. Steroid receptor in the ovary and uterus. In: JIMMY, D. N.; KNOBIL, K.; NEILL'S, L. (Ed.) Physiology of Reproduction. 3th ed. Elsevier; 2006. p. 593-658.

CULLINGFORD, T. E.; POLLARD, J. W. RU 486 completely inhibits the action of progesterone on cell proliferation in the mouse uterus. J. Reprod. Fertil., v. 83, n. 2, p. 909-914, 1988.

DE HERTOGH, R.; VANDERHEYDEN, I.; GLORIEUX, B.; EKKA, E. Oestrogen and progestogen receptors in endometrium and myometrium at the time of blastocyst implantation in pregnant diabetic rats. Diabetologia, v. 32, n. 8, p. 568-572, 1989.

DEFRONZO, R. A. Pathogenesis of type 2 diabetes mellitus. Med. Clin. North Am., v. 88, n. 4 , p. $787-835,2004$.

EIKA, B. et al. 3H-thymidine uptake by the rat urinary bladder after induction of diabetes mellitus. J. Urol., v. 150, n. 4, p. 1316-1320, 1993.

ELLEDGE, S. J. Cell cycle checkpoints: preventing an identity crisis. Science, v. 274, n. 5293, p. 1664-1672, 1996.

ENGELGAU, M. M.; HERMAN, W. H.; SMITH, P. J.; GERMAN, R. R.; AUBERT, R. E. The epidemiology of diabetes and pregnancy in the U.S., 1988. Diabetes Care, v. 18, n. 7, p. 1029-1033, 1995. 
FANG, Z.; YANG, S.; LYDON, J. P.; DEMAYO, F.; TAMURA, M.; GURATES, B.; BULUN, S. E. Intact progesterone receptors are essential to counteract the proliferative effect of estradiol in a genetically engineered mouse model of endometriosis. Fertil. Steril., v. 82, n. 3, p. 673-678, 2004.

FAVARO, R. R.; RASPANTINI, P. R.; SALGADO, R. M.; FORTES, Z. B.; ZORN, T. $M$. Long-term type 1 diabetes alters the deposition of collagens and proteoglycans in the early pregnant myometrium of mice. Histol. Histopathol., v. 30, n. 4, p. 435-444, 2015.

FAVARO, R. R.; SALGADO, R. M.; COVARRUBIAS, A. C.; BRUNI, F.; LIMA, C.; FORTES, Z. B.; ZORN, T. M. Long-term type 1 diabetes impairs decidualization and extracellular matrix remodeling during early embryonic development in mice. Placenta, v. 34, n. 12, p. 1128-1135, 2013.

FAVARO, R. R. Ciclo celular e mitose. In: SIVIERO, F. (Ed.) Bases moleculares e metodologia de pesquisa. São Paulo: Rocca, 2013. p. 277-296.

FAVARO, R. R.; SALGADO, R. M.; RASPANTINI, P. R.; FORTES, Z. B.; ZORN, T. $M$. Effects of long-term diabetes on the structure and cell proliferation of the myometrium in the early pregnancy of mice. Int. J. Exp. Pathol., v. 91, n. 5, p. 426435, 2010.

FLEISCH, M. C.; CHOU, Y. C.; CARDIFF, R. D.; ASAITHAMBI, A.; SHYAMALA, G. Overexpression of progesterone receptor $A$ isoform in mice leads to endometrial hyperproliferation, hyperplasia and atypia. Mol. Hum. Reprod., v. 15, n. 4, p. 241249, 2009.

FRANCO, H. L.; JEONG, J. W.; TSAI, S. Y.; LYDON, J. P.; DEMAYO, F. J. In vivo analysis of progesterone receptor action in the uterus during embryo implantation. Semin. Cell Dev. Biol, v. 19, n. 2, p. 178-186, 2008.

FREINKEL, N. Banting Lecture 1980. Of pregnancy and progeny. Diabetes, v. 29, n. 12, p. 1023-1035, 1980.

FU, X. D.; ARES, M., JR. Context-dependent control of alternative splicing by RNAbinding proteins. Nat. Rev. Genet., v. 15, n. 10, p. 689-701, 2014.

GARRIS, D. R. Effects of diabetes on uterine condition, decidualization, vascularization, and corpus luteum function in the pseudopregnant rat. Endocrinology, v. 122, n. 2, p. 665-672, 1988.

GARRIS, D. R.; WHITEHEAD, D. S.; MORGAN, C. R. Effects of alloxaninduced diabetes on corpus luteum function in the pseudopregnant rat. Diabetes, $\mathrm{V}$. 33, n. 7, p. 611-615, 1984.

GELLERSEN, B.; FERNANDES, M. S.; BROSENS, J. J. Non-genomic progesterone actions in female reproduction. Hum. Reprod. Update, v. 15, n. 1, p. 119-138, 2009. 
GIANGRANDE, P. H.; POLLIO, G.; MCDONNELL, D. P. Mapping and characterization of the functional domains responsible for the differential activity of the $A$ and $B$ isoforms of the human progesterone receptor. J. Biol. Chem., v. 272, n. 52, p. 32889-32900, 1997.

GLASSER, S. R.; APLIN, J. D.; GUIDICE, L. C.TABIBZADEH S. editor. The endometrium. London: Informa Healthcare; 2002.

GODBOLE, G. B.; MODI, D. N.; PURI, C. P. Regulation of homeobox A10 expression in the primate endometrium by progesterone and embryonic stimuli. Reproduction, v. 134, n. 3, p. 513-523, 2007.

GRIFFIN, M. L.; SOUTH, S. A.; YANKOV, V. I.; BOOTH, R. A., JR.; ASPLIN, C. M.; VELDHUIS, J. D.; EVANS, W. S. Insulin-dependent diabetes mellitus and menstrual dysfunction. Ann. Med., v. 26, n. 5, p. 331-340, 1994.

HANTAK, A. M.; BAGCHI, I. C.; BAGCHI, M. K. Role of uterine stromal-epithelial crosstalk in embryo implantation. Int. J. Dev. Biol., v. 58, n. 2-4, p. 139-146, 2014.

HOVLAND, A. R.; POWELL, R. L; TAKIMOTO, G. S.; TUNG, L.; HORWITZ, K. B. An $\mathrm{N}$-terminal inhibitory function, IF, suppresses transcription by the A-isoform but not the B-isoform of human progesterone receptors. J. Biol. Chem., v. 273, n. 10, p. 5455-5460, 1998.

HUNT, K. J.; SCHULLER, K. L. The increasing prevalence of diabetes in pregnancy. Obstet Gynecol. Clin. North. Am., v. 34, n. 2, p. 173-199, 2007.

Hyperglycaemia and Adverse Pregnancy Outcome (HAPO) Study: associations with maternal body mass index. Bjog., v. 117, n. 5, p. 575-584, 2010.

IVANISEVIC, M.; BUKOVIC, D.; STARCEVIC, V.; DJELMIS, J.; PFEIFER, D. Influence of hyperglycemia on early embryonal growth in IDDM pregnant women. Coll. Antropol., v. 23, n. 1, p. 183-188, 1999.

JAWERBAUM, A.; GONZALEZ, E. Diabetic pregnancies: the challenge of developing in a pro-inflammatory environment. Curr. Med. Chem., v. 13, n. 18, p. 2127-2138, 2006.

JENSEN, D. M.; DAMM, P.; MOELSTED-PEDERSEN, L.; OVESEN, P.; WESTERGAARD, J. G.; MOELLER, M.; BECK-NIELSEN, H. Outcomes in type 1 diabetic pregnancies: a nationwide, population-based study. Diabetes Care, v. 27, n. 12, p. 2819-2823, 2004.

JONES, S. R.; KIMLER, B. F.; JUSTICE, W. M.; RIDER, V. Transit of normal rat uterine stromal cells through $\mathrm{G} 1$ phase of the cell cycle requires progesterone-growth factor interactions. Endocrinology, v. 141, n. 2, p. 637-648, 2000.

JUNQUEIRA, J. C.; CARNEIRO J. Histologia básica. 11. ed. Rio de Janeiro: Guanabara Koogan, 2008. 
JUNQUEIRA, J. C.; CARNEIRO J. Biologia celular e molecular. 8. ed. Rio de Janeiro: Guanabara Koogan, 2005.

KAPUR, S.; TAMADA, H.; DEY, S. K.; ANDREWS, G. K. Expression of insulin-like growth factor-I (IGF-I) and its receptor in the peri-implantation mouse uterus, and cell-specific regulation of IGF-I gene expression by estradiol and progesterone. Biol. Reprod., v. 46, n. 2, p. 208-219, 1992.

KASTNER, P.; KRUST, A.; TURCOTTE, B.; STROPP, U.; TORA, L.; GRONEMEYER, H.; CHAMBON, P. Two distinct estrogen-regulated promoters generate transcripts encoding the two functionally different human progesterone receptor forms A and B. Embo. J., v. 9, n. 5, p. 1603-1614, 1990.

KIENAST, S. G.; FADDEN, C.; STEGER, R. W. Streptozotocin-induced diabetes blocks the positive feedback release of luteinizing hormone in the female rat. Brain. Res. Bull., v. 32, n. 4, p. 399-405, 1993.

KIM, M.; PARK, H. J.; SEOL, J. W.; JANG, J. Y.; CHO, Y. S.; KIM, K. R.; CHOI, Y.; LYDON, J. P.; DEMAYO, F. J.; SHIBUYA, M.; FERRARA, N.; SUNG, H. K.; NAGY, A.; ALITALO, K.; KOH, G. Y. VEGF-A regulated by progesterone governs uterine angiogenesis and vascular remodelling during pregnancy. EMBO. Mol. Med., v. 5, n. 9, p. 1415-1430, 2013.

KIM, N. N.; STANKOVIC, M.; CUSHMAN, T. T.; GOLDSTEIN, I.; MUNARRIZ, R.; TRAISH, A. M. Streptozotocin-induced diabetes in the rat is associated with changes in vaginal hemodynamics, morphology and biochemical markers. BMC. Physiol., v. 6, p. 4, 2006.

KIRKLAND, J. L.; BARRETT, G. N.; STANCEL, G. M. Decreased cell division of the uterine luminal epithelium of diabetic rats in response to 17 beta-estradiol. Endocrinology, v. 109, n. 1, p. 316-318, 1981.

KRENNING, L.; FERINGA, F. M.; SHALTIEL, I. A.; VAN DEN BERG, J.; MEDEMA, R. H. Transient activation of p53 in G2 phase is sufficient to induce senescence. Mol. Cell., v. 55, n. 1, p. 59-72, 2014.

KURITA, T.; LEE, K. J.; COOKE, P. S.; TAYLOR, J. A.; LUBAHN, D. B.; CUNHA, G. $R$. Paracrine regulation of epithelial progesterone receptor by estradiol in the mouse female reproductive tract. Biol. Reprod., v. 62, n. 4, p. 821-830, 2000.

KUZNETSOVA, N. V.; Pal'chikova, N. A.; Kuzminova, O. I.; Selyatitskaya, V. G. Production of corticosteroid hormones in vitro by adrenals in rats with streptozotocininduced diabetes. Bull. Exp. Biol. Med., v. 157, n. 1, p. 28-31, 2014.

LABAER, J.; GARRETT, M. D.; STEVENSON, L. F.; SLINGERLAND, J. M.; SANDHU, C.; CHOU, H. S.; FATTAEY, A.; HARLOW, E. New functional activities for the p21 family of CDK inhibitors. Genes. Dev., v. 11, n. 7, p. 847-862, 1997. 
LAKHA, F.; HO, P. C.; VAN DER SPUY, Z. M.; DADA, K.; ELTON, R.; GLASIER, A. F.; CRITCHLEY, H. O.; WILLIAMS, A. R.; BAIRD, D. T. A novel estrogen-free oral contraceptive pill for women: multicentre, double-blind, randomized controlled trial of mifepristone and progestogen-only pill (levonorgestrel). Hum. Reprod., v. 22, n. 9, p. 2428-2436, 2007.

LAPOLLA, A.; DALFRA, M. G.; SPEZIA, R.; ANICHINI, R.; BONOMO, M.; BRUTTOMESSO, D.; DI CIANNI, G.; FRANZETTI, I.; GALLUZZO, A.; MELLO, G.; MENATO, G.; NAPOLI, A.; NOACCO, G.; PARRETTI, E.; SANTINI, C.; SCALDAFERRI, E.; SCALDAFERRI, L.; SONGINI, M.; TONUTTI, L.; TORLONE, E.; GENTILELLA, R.; ROSSI, A.; VALLE, D. Outcome of pregnancy in type 1 diabetic patients treated with insulin lispro or regular insulin: an Italian experience. Acta. Diabetol., v. 45, n. 1, p. 61-66, 2008.

LEONHARDT, S. A.; BOONYARATANAKORNKIT, V.; EDWARDS, D. P. Progesterone receptor transcription and non-transcription signaling mechanisms. Steroids, v. 68, n. 10-13, p. 761-770, 2003.

LI, Q.; KANNAN, A.; DEMAYO, F. J.; LYDON, J. P.; COOKE, P. S.; YAMAGISHI, H.; SRIVASTAVA, D.; BAGCHI, M. K.; BAGCHI, I. C. The antiproliferative action of progesterone in uterine epithelium is mediated by Hand2. Science, v. 331, n. 6019, p. 912-916, 2011.

LIM, H.; MA, L.; MA, W. G.; MAAS, R. L.; DEY, S. K. Hoxa-10 regulates uterine stromal cell responsiveness to progesterone during implantation and decidualization in the mouse. Mol. Endocrinol., v. 13, n. 6, p. 1005-1017, 1999.

LIU, M.; ZHANG, Y.; CHI, Y.; ZHAI, S.; WANG, B.; SHI, Y.; LI, Y.I. Delivery of megsin siRNA plasmid reveals therapeutic potential against diabetic nephropathy by downregulating p27(kip1) level. J. Nephrol., v. 25, n. 3, p. 418-425, 2012.

LIVAK, K. J.; SCHMITTGEN, T. D. Analysis of relative gene expression data using real-time quantitative PCR and the 2(-Delta Delta C(T)) Method. Methods, v. 25, n. 4, p. 402-408, 2001.

LURIE, A. O.; REID, D. E.; VILLEE, C. A. The role of the fetus and placenta in maintenance of plasma progesterone. Am. J. Obstet. Gynecol., v. 96, n. 5, p. 670675, 1966.

LYDON, J. P.; DEMAYO, F. J.; FUNK, C. R.; MANI, S. K.; HUGHES, A. R.; MONTGOMERY, C. A., JR.; SHYAMALA, G.; CONNEELY, O. M.; O'MALLEY, B. W. Mice lacking progesterone receptor exhibit pleiotropic reproductive abnormalities. Genes Dev., v. 9, n. 18, p. 2266-2278, 1995.

MANI, S. K.; ALLEN, J. M.; LYDON, J. P.; MULAC-JERICEVIC, B.; BLAUSTEIN, J. D.; DEMAYO, F. J.; CONNEELY, O.; O'MALLEY, B. W. Dopamine requires the unoccupied progesterone receptor to induce sexual behavior in mice. Mol. Endocrinol., v. 10, n. 12, p. 1728-1737, 1996. 
MARTIN, L.; FINN, C. A. Hormonal regulation of cell division in epithelial and connective tissues of the mouse uterus. J. Endocrinol., v. 41, n. 3, p. 363-371, 1968.

MATSUMOTO, H.; ZHAO, X.; DAS, S. K.; HOGAN, B. L.; DEY, S. K. Indian hedgehog as a progesterone-responsive factor mediating epithelial-mesenchymal interactions in the mouse uterus. Dev. Biol., v. 245, n. 2, p. 280-290, 2002.

METZGER, B. E.; LOWE, L. P.; DYER, A. R.; TRIMBLE, E. R.; CHAOVARINDR, U.; COUSTAN, D. R.; HADDEN, D. R.; MCCANCE, D. R.; HOD, M.; MCINTYRE, H. D.; OATS, J. J.; PERSSON, B.; ROGERS, M. S.; SACKS, D. A. Hyperglycemia and adverse pregnancy outcomes. N. Engl. J. Med., v. 358, n. 19, p. 1991-2002, 2008.

MOTE, P. A.; ARNETT-MANSFIELD, R. L.; GAVA, N.; DEFAZIO, A.; MULACJERICEVIC, B.; CONNEELY, O. M.; CLARKE, C. L. Overlapping and distinct expression of progesterone receptors $A$ and $B$ in mouse uterus and mammary gland during the estrous cycle. Endocrinology, v. 147, n. 12, p. 5503-5512, 2006.

MOTE, P. A.; GOMPEL, A.; HOWE, C.; HILTON, H. N.; SESTAK, I.; CUZICK, J.; DOWSETT, M.; HUGOL, D.; FORGEZ, P.; BYTH, K.; GRAHAM, J. D.; CLARKE, C. $\mathrm{L}$. Progesterone receptor A predominance is a discriminator of benefit from endocrine therapy in the ATAC trial. Breast Cancer Res. Treat., v. 151, n. 2, p. 309-318, 2015.

MULAC-JERICEVIC, B.; LYDON, J. P.; DEMAYO, F. J.; CONNEELY, O. M. Defective mammary gland morphogenesis in mice lacking the progesterone receptor B isoform. Proc Natl. Acad. Sci. U S A, v. 100, n. 17, p. 9744-9749, 2003.

MULAC-JERICEVIC, B.; MULLINAX, R. A.; DEMAYO, F. J.; LYDON, J. P.; CONNEELY, O. M. Subgroup of reproductive functions of progesterone mediated by progesterone receptor-B isoform. Science, v. 289, n. 5485, p. 1751-1754, 2000.

MUSGROVE, E. A.; SUTHERLAND, R. L. Cell cycle control by steroid hormones. Semin. Cancer Biol., v. 5, n. 5, p. 381-399, 1994.

NATARAJAN, R.; GONZALES, N.; XU, L.; NADLER J. L. Vascular smooth muscle cells exhibit increased growth in response to elevated glucose. Biochem. Biophys. Res. Commun., v. 187, n. 1, p. 552-560, 1992.

OTANI, H.; TANAKA, O.; TATEWAKI, R.; NAORA, H.; YONEYAMA, T. Diabetic environment and genetic predisposition as causes of congenital malformations in NOD mouse embryos. Diabetes, v. 40, n. 10, p. 1245-1250, 1991.

PARDEE, A. B. A restriction point for control of normal animal cell proliferation. Proc. Natl. Acad. Sci. U S A, v. 71, n. 4, p. 1286-1290, 1974.

PARIA, B. C.; MA, W.; TAN, J.; RAJA, S.; DAS, S. K.; DEY, S. K.; HOGAN, B. L. Cellular and molecular responses of the uterus to embryo implantation can be elicited by locally applied growth factors. Proc. Natl. Acad. Sci. U S A, v. 98, n. 3, p. 10471052, 2001. 
PATEL, B.; ELGUERO, S.; THAKORE, S.; DAHOUD, W.; BEDAIWY, M.; MESIANO, $\mathrm{S}$. Role of nuclear progesterone receptor isoforms in uterine pathophysiology. Hum. Reprod. Update, v. 21, n. 2, p. 155-173, 2015.

PAWAR, S.; LAWS, M. J.; BAGCHI, I. C.; BAGCHI, M. K. Uterine Epithelial Estrogen Receptor-alpha Controls Decidualization via a Paracrine Mechanism. Mol. Endocrinol., v. 29, n. 9, p. 1362-1374, 2015.

RADAELLI, T.; VARASTEHPOUR, A.; CATALANO, P.; HAUGUEL-DE MOUZON, S. Gestational diabetes induces placental genes for chronic stress and inflammatory pathways. Diabetes, v. 52, n. 12, p. 2951-2958, 2003.

REINIUS, S. Ultrastructure of blastocyst attachment in the mouse. Z. Zellforsch Mikrosk Anat., v. 77, n. 2, p. 257-266, 1967.

RIDER, V. Progesterone and the control of uterine cell proliferation and differentiation. Front. Biosci., v. 7, p. d1545-1555, 2002.

RIDER, V.; ISUZUGAWA, K.; TWAROG, M.; JONES, S.; CAMERON, B.; IMAKAWA, K.; FANG, J. Progesterone initiates Wnt-beta-catenin signaling but estradiol is required for nuclear activation and synchronous proliferation of rat uterine stromal cells. J. Endocrinol., v. 191, n. 3, p. 537-548, 2006.

RIDER, V.; PSYCHOYOS, A. Inhibition of progesterone receptor function results in loss of basic fibroblast growth factor expression and stromal cell proliferation during uterine remodelling in the pregnant rat. J. Endocrinol., v. 140, n. 2, p. 239-249, 1994.

ROSENFELD, C. R. Insulin therapy in type 2 diabetes mellitus: history drives patient care toward a better future. J. Am. Osteopath. Assoc., v. 113, n. 4, p. S4-5, 2013. Suppl 2.

RUGH, R. The mouse: reproduction and development. Minneapolis. Burgess Publishing Company; 1968.

SALGADO, R. M.; FAVARO, R. R.; ZORN, T. M. Modulation of small leucine-rich proteoglycans (SLRPs) expression in the mouse uterus by estradiol and progesterone. Reprod. Biol. Endocrinol., v. 9, p. 22, 2011.

SALGADO, R. M.; CAPELO, L. P.; FAVARO, R.; GLAZIER, J.D.; APLIN, J. D.; ZORN, T. M. Hormone-regulated expression and distribution of versican in mouse uterine tissues. Reprod. Biol. Endocrinol., v. 7, p. 60, 2009.

SALGADO, R. M.; COVARRUBIAS, A. C.; FAVARO, R.; SERRANO-NASCIMENTO, C.; NUNES, M. T.; ZORN, T. M. Estradiol induces transcriptional and posttranscriptional modifications in versican expression in the mouse uterus. J. Mol. Histol., v. 44, n. 2, p. 221-229, 2013. 
SASAKI, M.; DHARIA, A.; OH, B. R.; TANAKA, Y.; FUJIMOTO, S.; DAHIYA, R. Progesterone receptor $B$ gene inactivation and $\mathrm{CpG}$ hypermethylation in human uterine endometrial cancer. Cancer Res., v. 61, n. 1, p. 97-102, 2001.

SATOKATA, I.; BENSON, G.; MAAS, R. Sexually dimorphic sterility phenotypes in Hoxa10-deficient mice. Nature, v. 374, n. 6521, p. 460-463, 1995.

SELYATITSKAYA, V. G.; PALCHIKOVA, N. A.; KUZNETSOVA N. V. Adrenocortical system activity in alloxan-resistant and alloxan-susceptible Wistar rats. Journal of Diabetes Mellitus, v. 2, n. 2, p. 165-169, 2012.

SHAW, K. A.; TOPP, N. J.; SHAW, J. G.; BLUMENTHAL, P. D. Mifepristonemisoprostol dosing interval and effect on induction abortion times: a systematic review. Obstet. Gynecol., v. 121, n. 6, p. 1335-1347, 2013.

SHIOZAWA, T.; NIKAIDO, T.; NAKAYAMA, K.; LU, X.; FUJII, S. Involvement of cyclin-dependent kinase inhibitor p27Kip1 in growth inhibition of endometrium in the secretory phase and of hyperplastic endometrium treated with progesterone. Mol. Hum. Reprod., v. 4, n. 9, p. 899-905, 1998.

SHORR, E. A new technic for staining vaginal smears: III, a single differential stain. Science, v. 94, n. 2449, p. 545-546, 1941.

SIBBITT, W. L.; MILLS, R. G.; BIGLER, C. F.; EATON, R. P.; GRIFFEY, R. H.; VANDER JAGT, D. L. Glucose inhibition of human fibroblast proliferation and response to growth factors is prevented by inhibitors of aldose reductase. Mech. Ageing. Dev., v. 47, n. 3, p. 265-279, 1989.

SMITH, D. L.; STINEFELT, B. M.; BLEMINGS, K. P.; WILSON, M. E. Diet-induced alterations in progesterone clearance appear to be mediated by insulin signaling in hepatocytes. J. Anim. Sci., v. 84, n. 5, p. 1102-1109, 2006.

SPENCER, S. L.; CAPPELL, S. D.; TSAI, F. C.; OVERTON, K. W.; WANG, C. L.; MEYER, T. The proliferation-quiescence decision is controlled by a bifurcation in CDK2 activity at mitotic exit. Cell, v. 155, n. 2, p. 369-383, 2013.

SPITZ, I. M.; CROXATTO, H. B.; LAHTEENMAKI, P.; HEIKINHEIMO, O.; BARDIN, C. W. Effect of mifepristone on inhibition of ovulation and induction of luteolysis. Hum. Reprod., v. 9 Suppl 1, p. 69-76, 1994.

STILLMAN, B. Cell cycle control of DNA replication. Science, v. 274, n. 5293, p. 1659-1664, 1996.

SUTHERLAND, R. L.; PRALL, O. W.; WATTS, C. K.; MUSGROVE, E. A. Estrogen and progestin regulation of cell cycle progression. J. Mammary Gland. Biol. Neoplasia., v. 3, n. 1, p. 63-72, 1998.

TATEWAKI, R.; OTANI, H.; TANAKA, O.; KITADA, J. A morphological study on the reproductive organs as a possible cause of developmental abnormalities in diabetic NOD mice. Histol. Histopathol., v. 4, n. 3, p. 343-358, 1989. 
TUCKEY, R. C. Progesterone synthesis by the human placenta. Placenta, v. 26, n. 4, p. 273-281, 2005.

VARGAS, R.; REPKE, J. T.; URAL, S. H. Type 1 diabetes mellitus and pregnancy. Rev. Obstet. Gynecol., v. 3, n. 3, p. 92-100, 2010.

VEGETO, E.; SHAHBAZ, M. M.; WEN, D. X.; GOLDMAN, M. E.; O'MALLEY, B. W.; MCDONNELL, D. P. Human progesterone receptor A form is a cell- and promoterspecific repressor of human progesterone receptor B function. Mol. Endocrinol., v. 7, n. 10, p. 1244-1255, 1993.

WOLF, G.; SCHROEDER, R.; ZAHNER, G.; STAHL, R. A.; SHANKLAND, S. J. High glucose-induced hypertrophy of mesangial cells requires p27(Kip1), an inhibitor of cyclin-dependent kinases. Am. J. Pathol., v. 158, n. 3, p. 1091-1100, 2001.

WOOD, G. A.; FATA, J. E.; WATSON, K. L.; KHOKHA, R. Circulating hormones and estrous stage predict cellular and stromal remodeling in murine uterus. Reproduction, v. 133, n. 5, p. 1035-1044, 2007.

YUE, L.; DAIKOKU, T.; HOU, X.; LI, M.; WANG, H.; NOJIMA, H.; DEY, S. K.; DAS, S. K. Cyclin G1 and cyclin G2 are expressed in the periimplantation mouse uterus in a cell-specific and progesterone-dependent manner: evidence for aberrant regulation with Hoxa-10 deficiency. Endocrinology, v. 146, n. 5, p. 2424-2433, 2005.

ZAKARIA, R.; ISMAIL, Z.; CHATTERJEE, A. Cyproterone acetate and reversal of the impaired endometrial decidualization in streptozotocin-diabetic pseudopregnant rats. Pharmacol. Res., v. 42, n. 2, p. 183-186, 2000.

ZHU, L.; POLLARD, J. W. Estradiol-17beta regulates mouse uterine epithelial cell proliferation through insulin-like growth factor 1 signaling. Proc. Natl. Acad. Sci. U S A, v. 104, n. 40, p. 15847-15851, 2007.

ZORN, T. M.; SOTO-SUAZO, M.; PELLEGRINI, C. R.; OLIVEIRA, J. G.; STUMPF, W. E. Estradiol receptor binding to the epithelium of uterine lumen and glands: region- and time-related changes during preimplantation and periimplantation periods studied by autoradiography. Histochem. Cell Biol., v. 120, n. 1, p. 1-12, 2003.

ZORN, T. M.; ZÚÑIGA, M.; MADRID, E.; TOSTES, R.; FORTES, Z.; GIACHINI, F.; SAN MARTíN, S. I. Maternal diabetes affects cell proliferation in developing rat placenta. Histol. Histopathol., v. 26, n. 8, p. 1049-1056, 2011. 
APÊNDICE - Protocolo da técnica histoquímica do Picrosirius

\section{1) Desparafinização}

- Xilol I - II - 30 minutos cada

\section{2) Hidratação}

- Álcool Absoluto - 95\% - 90\% - 70\% - 30 minutos cada

- Água destilada - 5 minutos

\section{3) Coloração}

- Picrosirius - 1 hora (sob agitação)

- Água corrente - 15 minutos

- Água destilada. - lavagem rápida

- Hematoxilina de Mayer - 6 minutos

- Água corrente - 10 minutos

- Água destilada - 5 minutos

\section{4) Desidratação e diafanização}

- Álcool - 95\% - 1 minuto (passagem rápida)

- Álcool Abs I - 2 minutos

- Álcool Abs II - 5 minutos

- Álcool / xilol (1:1) - - 5 minutos

- Xilol I e II - 15 minutos cada

5) Montagem

- Montagem das lâminas com resina e lamínula de vidro 